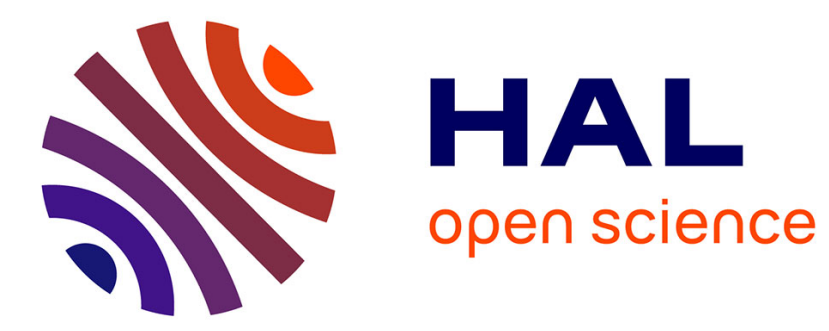

\title{
Analytic essay on the domestic statuary of central Hunan. The cult to divinities, parents and masters
}

\author{
Alain Arrault
}

\section{To cite this version:}

Alain Arrault. Analytic essay on the domestic statuary of central Hunan. The cult to divinities, parents and masters. Journal of Chinese Religions, 2008, 36, pp.1-53. halshs-00959723

\section{HAL Id: halshs-00959723 \\ https://shs.hal.science/halshs-00959723}

Submitted on 15 Mar 2014

HAL is a multi-disciplinary open access archive for the deposit and dissemination of scientific research documents, whether they are published or not. The documents may come from teaching and research institutions in France or abroad, or from public or private research centers.
L'archive ouverte pluridisciplinaire HAL, est destinée au dépôt et à la diffusion de documents scientifiques de niveau recherche, publiés ou non, émanant des établissements d'enseignement et de recherche français ou étrangers, des laboratoires publics ou privés. 


\title{
Analytic Essay on the Domestic Statuary of Central Hunan: The Cult to Divinities, Parents, and Masters
}

\author{
AlAIN ARRAULT \\ Ecole française d'Extrême-Orient (EFEO) \\ University of Liège (Belgium)
}

\section{Introduction}

Thanks to the financial support of the CCK Foundation and the Beaufour-Ipsen Tianjin Pharmaceutical Co., the Beijing Centre of the Ecole Française d'Extrême-Orient has been engaged in a research project entitled "Taoism and Local Society," since 2002. The project was based on the computerized cataloging of three collections of polychrome wood statuettes originating in the Hunan region. Two are private collections and the third belongs to the Hunan Provincial Museum, the same that houses the Mawangdui relics. At this point, the cataloguing of two collections is complete, that of Patrice Fava (hereafter noted as PF) and that of the Museum (hereafter noted as MH). ${ }^{1}$ Other than their differing origins, the particularity of these collections - compared to the one constituted by De Groot at the turn of the 20th century in the Fujian area, which one can visit in Lyon and in Leiden ${ }^{2}$-resides in the fact that the statuettes have been consecrated and that they contain an yizhi 意旨 (consecration certificate) precisely indicating the name of the statuette, those who commissioned it, the

This paper was translated into English by Daniel Burton-Rose. John Lagerwey has kindly read this article and made very helpful remarks and suggestions; David Palmer and James Robson carefully corrected and amended the last version. I also benefited from two anonymous reviewers' corrections.

${ }^{1}$ See Arrault ed, in collaboration with Michela Bussotti, Patrice Fava, Li Feng, Zhang Yao et al, Les statuettes religieuses du Hunan. 1. La collection Patrice Fava, and Alain Arrault ed, in collaboration with Michela Bussotti, Deng Zhaohui, Li Feng, Shen Jinxian, Zhang Yao, Les statuettes religieuses du Hunan. 2. La collection du musée du Hunan. Two other collections are currently being catalogued: one belonging to Yan Xinyuan, a private collector from Hunan (cataloguing by the present author); and one belonging to an American antique dealer in Milwaukee (cataloguing by James Robson).

${ }^{2}$ These two collections are stored at the Muséum d'histoire naturelle de Lyon and the National Museum of Ethnology in Leiden. A catalogue of these approximately 250 statuettes is published in Z. Werblowski, "Catalogue of the Pantheon of Fujian Popular Religion", p. 111-186. An exhibition was held in 2003 at the Muséum d'Histoire naturelle de Lyon, cf. Emmons, Dieux de Chine. 
sculptors, the precise location of the home where it was installed, the reason for the cult, the date of consecration, and generally a series of talismans intended to invoke the divinities. ${ }^{3}$ Based on the data currently at our disposal, we propose, first of all, to present these statuettes from a quantitative, temporal and geographical point of view, and secondly, to do a preliminary analysis of the three types of cults which are evoked in them: cults to divinities, parents and masters.

\section{General Presentation}

\subsection{Cataloguing}

In order to cross-analyze all the statuettes, we used a computerized relational database, with the format, entries and functions created for this purpose. Each statuette and its content has a corresponding data-card divided in two parts: in addition to the cataloguing number, ${ }^{4}$ the first part provides the origin, place of acquisition and identity of the person to whom it was dedicated, information on the material aspect of the statuette, the size, the physical attributes-which include the "magical gestures" (shoujue 手訣) and a precise description concerning the quality and the nature of the sculpture, the coloring and other details that reveal the different stages of manufacture - the clothes and the headgear. This part closes with an inventory of objects (consecration certificate, medicinal packets, paper money, etc.) found in the cache in the back of the statuette. The second part contains an inventory of all the information provided on the consecration certificate (see Pl. 1a), beginning with the nature of the writing itself (handwritten or printed), the address of the donor(s), as well as his or their names, the name of the religious lineage, the reason for the consecration, a description of the talismans, the name of the sculptor and the date of consecration. Two final columns are dedicated to notes and remarks, and the problems that can arise in understanding certain data (see Pl. 1b). The computer program was designed in such a way that all the fields can be an object of research. The cataloguing of the two collections followed the same protocol, with the exception of certain editing rules that time and experience permitted us to improve.

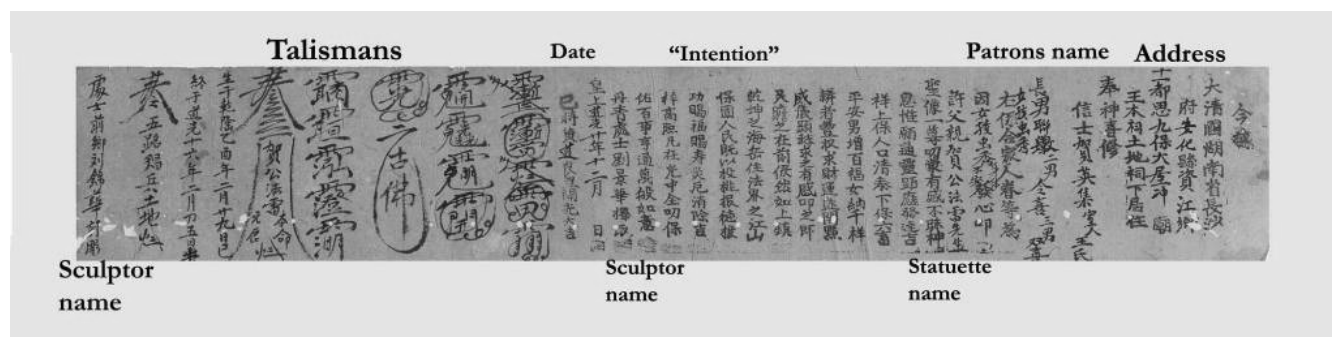

\footnotetext{
${ }^{3}$ This kind of statuette was first presented by Keith Stevens, "Altar Images from Hunan and Kiangsi." See also Stevens, "Portraits and Ancestral Images on Chinese Altars".

${ }^{4}$ The cataloguing number of the PF collection begins by "T" followed by four ciphers, the one of MH by four ciphers.
} 
P1. 1a: Example of a consecration certificate, made for the consecration of a statuette for $\mathrm{He}$ gong Falei (1765-1836) by his son, daughter-in-law, grandsons and granddaughter

in 1840 (T0781) OEFEO

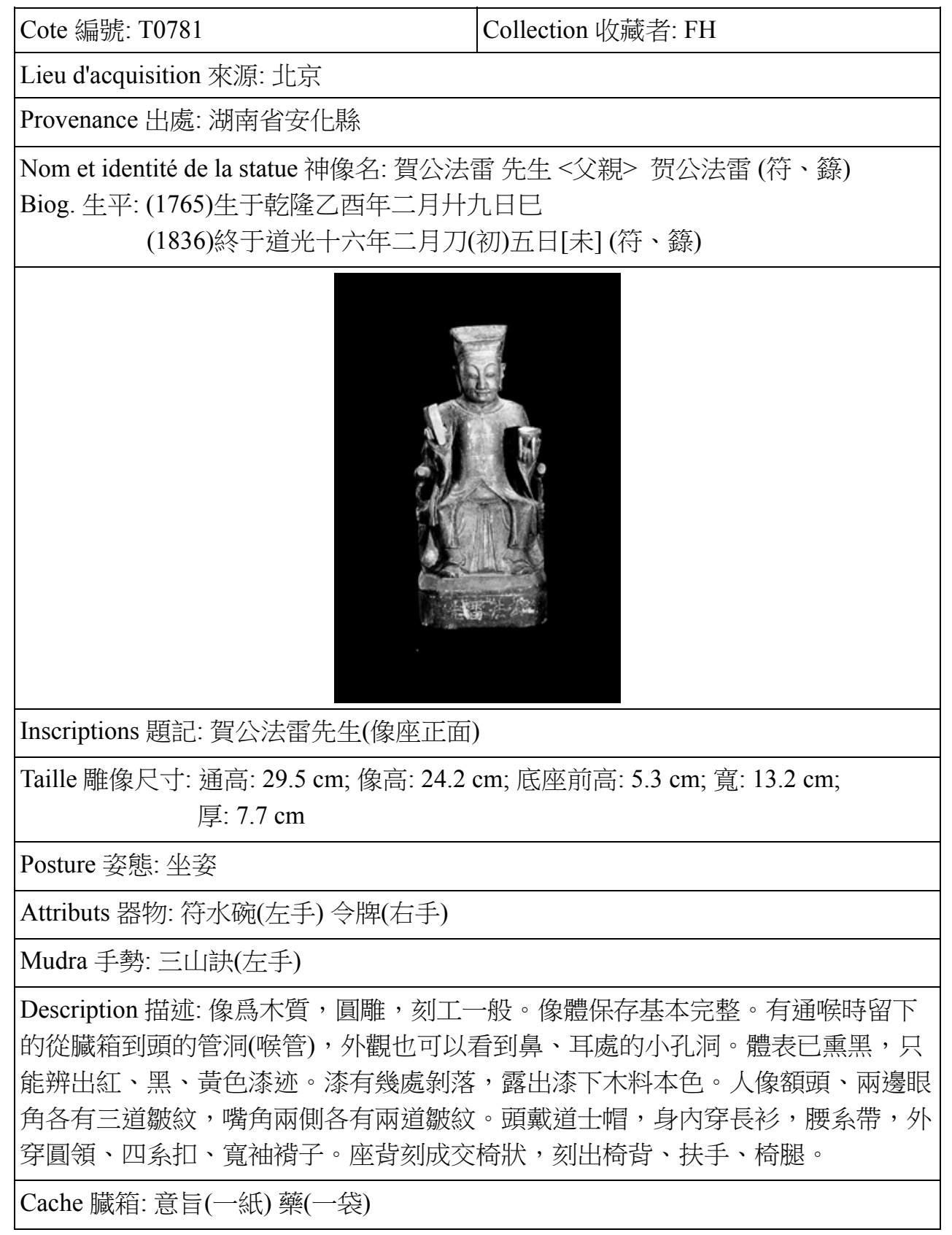


4 Journal of Chinese Religions

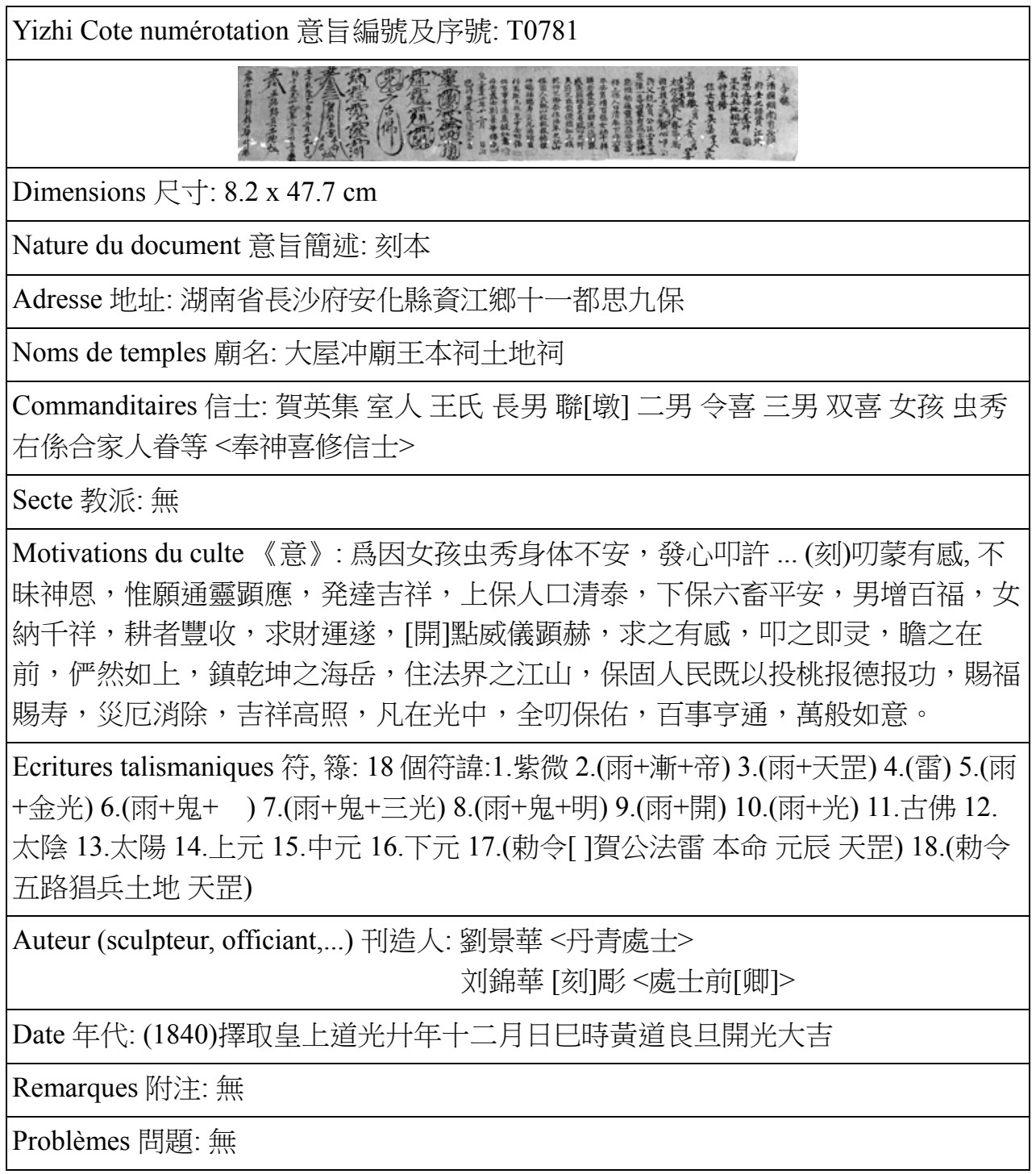

Pl. 1b: Sample of completed data-card (T0781)

\subsection{Quantitative Data}

The addresses of the 1,780 data-cards of the PF (909) and MH (871) collections show that the greatest number of statuettes come from Anhua district in Hunan, followed, in order, by Xinhua, Ningxiang, Yiyang, Xiangxiang, Shaoyang, Wugang and Longhui (see Table 1).

Table 1: Geographical distribution of the statuettes (PF and MH collections) 


\begin{tabular}{|l|c||c|c|}
\hline \multicolumn{1}{|c|}{ Place name 地名 } & $\begin{array}{c}\text { Number of } \\
\text { occurrences 當案 }\end{array}$ & Place name 地名 & $\begin{array}{c}\text { Number of } \\
\text { occurrences 當案 }\end{array}$ \\
\hline Anhua 安化 & 314 & Xinning 新寧 & 3 \\
\hline Xinhua 新化 & 187 & Changning 常寧 & 2 \\
\hline Ningxiang 寧鄉 & 112 & Hengyang 衡陽 & 1 \\
\hline Yiyang 益陽 & 49 & Xiangtan 湘潭 & 1 \\
\hline Xiangxiang 湘鄉 & 24 & Liling 醴陵 & 1 \\
\hline Shaoyang 邵陽 & 13 & Lianyuan 漣源 & 1 \\
\hline Wugang 武岡 & 8 & Hunan 湖南省 & 7 \\
\hline Longhui 隆回 & 4 & Total & $\mathbf{7 2 7}$ \\
\hline
\end{tabular}

Guangxi Province: 3 (PF)

Guanyang 灌陽: 1

Quanzhou 全州: $2^{5}$

Jiangxi Province : 7 (PF)

Chongren 崇仁: 1

Fengcheng 豐城: 4

Linchuan 臨川 (Fuzhou 撫州): 1

Tonggu 銅鼓: $1^{6}$

Unknown origin: ${ }^{7} 980$

Uncertain origin: ${ }^{8} 64$

Total entries: 1781

${ }^{5}$ These two localities are situated in Northern Guangxi province, a few $\mathrm{km}$ from the Southern border of Hunan.

${ }^{6}$ Tonggu is located in Northwest Jiangxi, a short distance from the Northeast boundary of Hunan. Linchuan, Fengcheng and Chongren are located in central Jiangxi, within a radius of about $50 \mathrm{~km}$ from each other.

${ }^{7}$ This figure corresponds to the total number of statuettes for which no address is given, but for which other data are preserved in the yizhi or on inscriptions on the statuette itself, such as the date or the identity of the statuette, the sponsors or the sculptors.

${ }^{8}$ Total number of statuettes with incomplete addresses - not indicating the province or the district, or for which the address data is insufficient to determine the location with certitude. 


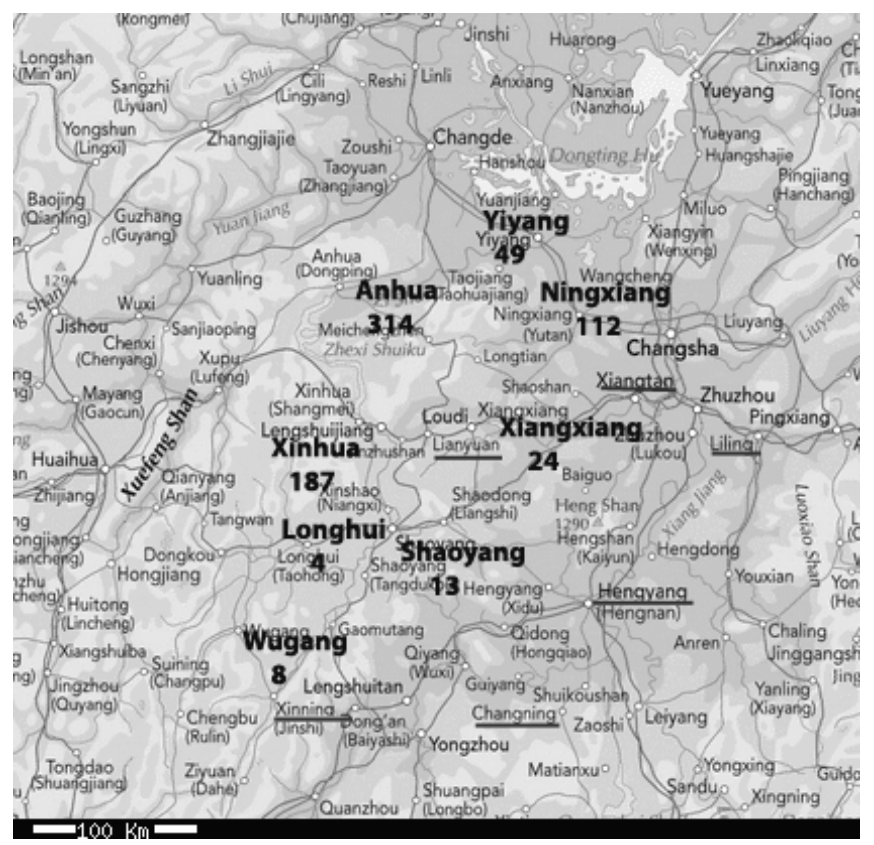

Map 1: Geographical distribution of statuettes in Hunan Province

The geographic distribution of the statues indicates that the epicenter of their production was in central and northwestern Hunan province (see Map 1), with several statues also coming from the adjoining provinces of Jiangxi and Guangxi (the PF collection). ${ }^{9}$ This region corresponds, more or less, to that which certain specialists have designated as the region of Meishan culture (Meishan wenhua 梅山文化). The way in which this culture was brought to the fore during the 1980s, with a thematic symposium organized for the first time in the 1990s, can certainly raise questions regarding the birth of this culture, which one could suspect of having been born of ideologico-touristical reasons, as was the case with a number of other local "cultures" during the same period. It should thus be pointed out that the name Meishan exists in historical texts, at least since the History of the Song (Songshi 宋史), and that certain certificates mention it explicitly. ${ }^{10}$ Nevertheless, the nature, components, and characteristics of this culture remain to be defined, an immense debate into which we will not enter in the

${ }^{9}$ Prof. Wang Yucheng, of the China Academy of Social Sciences, drew our attention to two statuettes with identical characteristics to those in Hunan, but crafted in Tongchuan county, Sichuan province, in 1899. However, the statuette's sponsors were emigrants to Sichuan, and consecrated these statuettes to honour masters from the Huguang 湖廣 region which, during the Qing, referred to the present-day provinces of Hubei and Hunan. Our thanks to Mr. Wang Yucheng for this precious information.

${ }^{10}$ The expression Meishan used for designating statuettes (Meishan shenxiang 梅山神像), spiritual masters (Meishan zushi 梅山祖師) or a religious order (Meishan zhengjiao 梅山正教), appears in certificates dating from the beginning to the mid 19th century. 
course of this study, except to mention in passing that they impact such complex factors as the supposed antiquity of the culture of non-Chinese ethnicities (Miao 苗 and Yao 瑤), the process of Sinicization starting with the Northern Song, the regular dispatch of troops to subdue local rebellions, and the migrations of significant numbers from the border regions, notably Jiangxi, towards Hunan as early as the Song and the Ming dynasties.

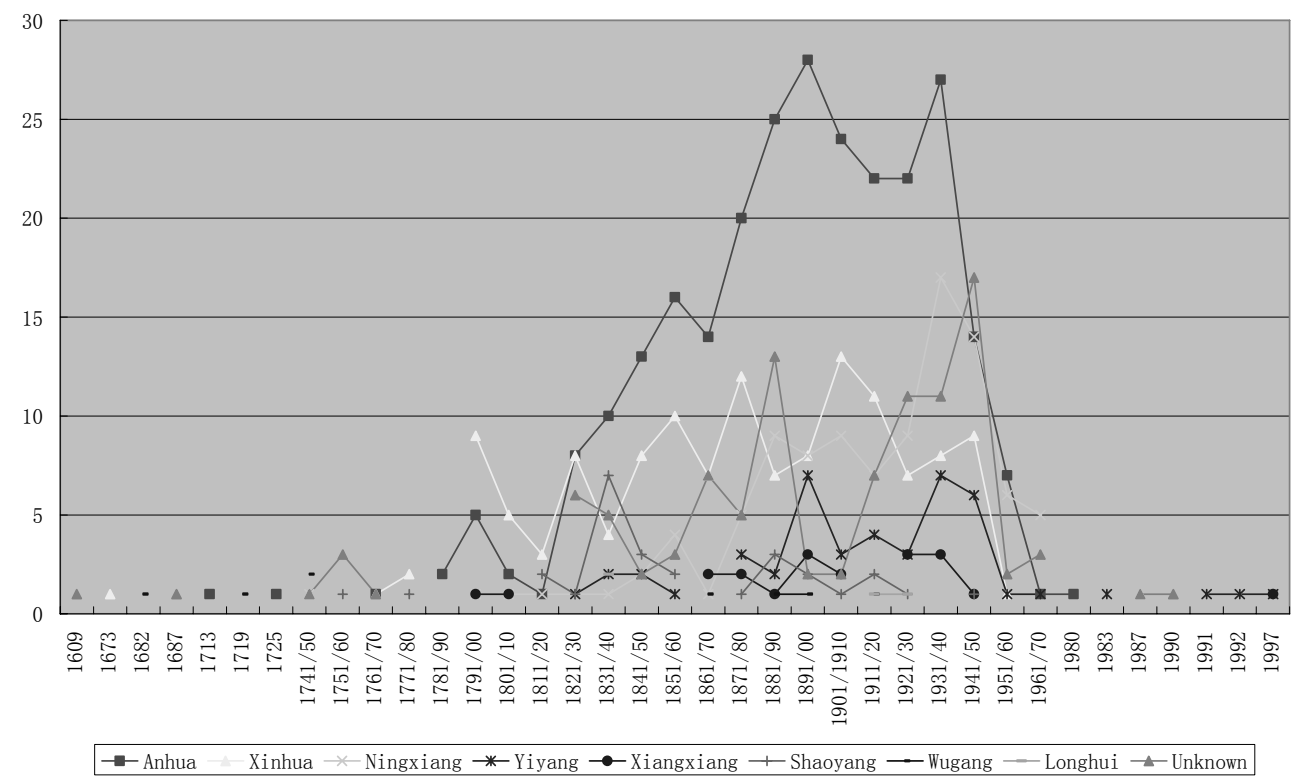

Graphic 1: Geographical and chronological distribution of the Hunan statuettes (PF and MH collections) $^{11}$

If we add the temporal dimension, ${ }^{12}$ to the spatial dimension (see Graphic 1 ) we notice that the oldest statue is preserved at the Hunan Provincial Museum and is dated - despite the absence of certificates, but thanks to an inscription engraved on its pedestal-1609 (Pl. 2) $)^{13}$. By means of morphological resemblance it can be linked to two other statuettes - of different dates

\footnotetext{
${ }^{11}$ In the interest of clarity, we have retained only those localities with a number of occurrences superior or equal to four.

${ }^{12}$ We based our findings on the consecration dates mentioned in the certificates. In the case of a double consecration, we have only kept the first date. For this reason in particular, in light of the fact that we cannot exclude the possibility of the manipulation of certificates, thus lacking reliable dating in the object itself, we cannot assert, particularly for the oldest, that the consecration date effectively corresponds to the date of statuette production.

${ }^{13}$ For more details, see Michela Bussotti, "Hunan zhongbu diqu jiating diaoxiang de lüeshu." A private collector from Hunan, Mr. Li Kui 李魁, owns a statuette for which the date, inscribed on the back of the cache door, is 1594, and which is dedicated to an exorcistic master, Zhou jun Fakui Liulang 周君法鬼斗六郎.
} 
(1778), granted, but of the same collection - one of which carries the name of Shangyuan yipin tianguan cifu ziwei dadi 上元一品天官賜福紫微大帝, the “Grand Emperor Ziwei (the name of the most important star at the center of the universe) Who Dispenses Happiness, Celestial Officer of First Rank of the Highest Origin." The three statuettes should thus represent the divinities of the highest, middle and lowest Origin (shang, zhong, xia Yuan 上, 中, 下元), that is the Officers of Heaven, Earth and Water (tian, di, shui guan 天地水官). The statuette from 1609, would have been situated on the altar to the left of the two others, as the Middle Origin (Zhongyuan erpin 中元二品) or the Officer of the Earth. ${ }^{14}$ A statuette dated to 1673 from the district of Xinhua, representing a master of exorcism (fashi 法師 or what was locally called shigong 師公), Xie Falong 謝法隆 (Pl. 3), was commissioned by a Zhang 張 family. ${ }^{15}$ The Zhang family designated the figure with the expression lao waizu 老外祖, the old ancestor of the "outer" lineage, which is to say that it concerns the maternal line. Chronologically, the next in order is a woman, Zhang shi Sanniang 張氏三娘 (Pl. 4), Zhang the Third Lady, to whom, in the district of Anhua in 1713, an effigy was consecrated requesting the protection of the mistress of the house who was pregnant at the age of 39 sui. In 1725, it was the turn of the celestial marshal Ma 馬元帥 (Pl. 5) to be rendered in the form of a statue and placed on an altar in the same district.
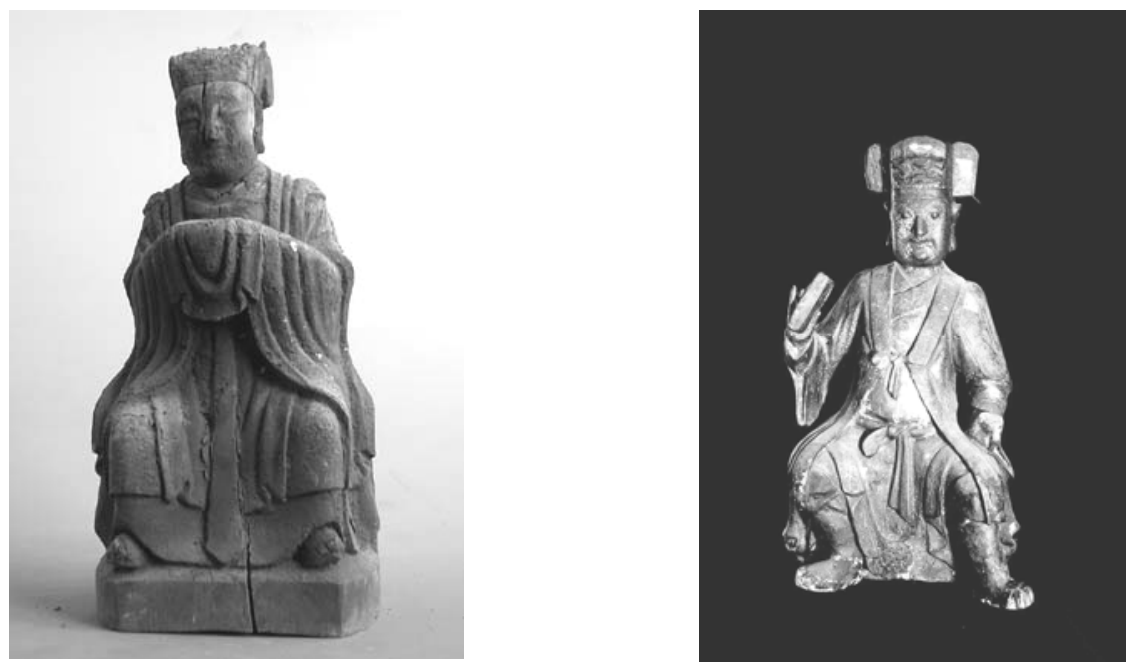

\footnotetext{
${ }^{14}$ One set of the same style comes from the FH collection (T1026-A, -B, -C). The name of the divinities is missing. Its record indicates that it comes from the district of Fengcheng in the province of Jiangxi. The divinity Zhongyuan erpin xianguan dadi 中元二品仙官大帝, coming from the district of Quanzhou in the province of Guangxi and consecrated in 1898 (T1008), represents probably the same divinity as the one of 1609 .

${ }^{15}$ For an historical approach to this kind of master in the Song Dynasty, rendered in English as "Ritual Masters", see Davis, Society and the Supernatural in Song China.
} 
P1. 2: The Officer of the Earth, 1609, h. $25.7 \mathrm{~cm}, 0819 / \mathrm{C}: 847$

Cliche Hunan Museum CEFEO

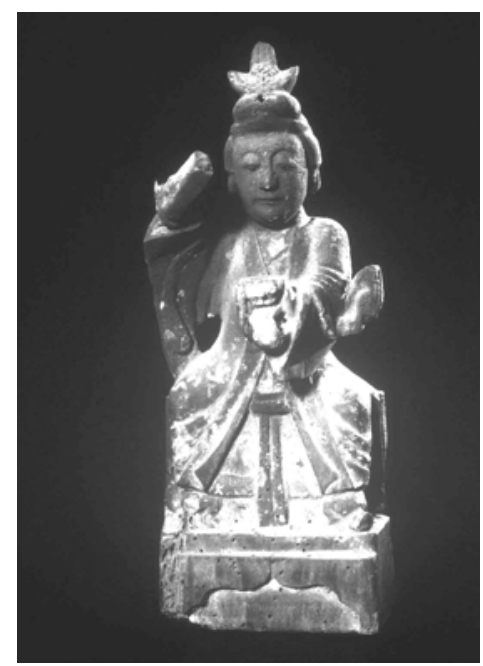

Pl. 4: Zhang shi Sanniang, Anhua, 1713, h. $28.5 \mathrm{~cm}, \mathrm{~T} 0103$ Cliche Claude Delhaye OEFEO
Pl. 3: Xie Falong, Xinhua, 1673, h. $45 \mathrm{~cm}, \mathrm{~T} 0604$

Cliche Zhang Chaoyin $\odot$ EFEO

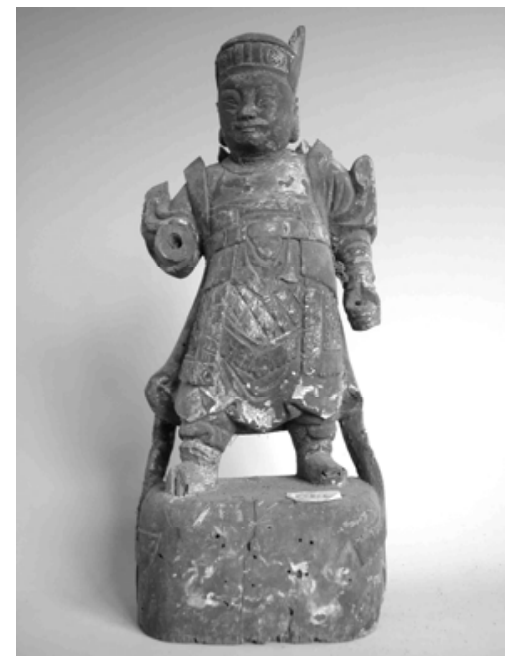

Pl. 5: Ma yuanshuai, Anhua, 1725, h. $31 \mathrm{~cm}, 0172 / \mathrm{C}: 806$

Cliche Hunan Museum CEFEO

These oldest examples are representative of a significant part of the two collections. We have thus far seen the Three Officers, a master of exorcism invested with liturgical powers for driving out malevolent forces and object of a cult reserved to ancestors, a woman, here charged with the protection of pregnancy, and a Celestial Marshal, also of national repute, upon whom one calls in rituals to exterminate disturbance-causing demons.

The $18^{\text {th }}$ century saw an increase in the appearance of statuettes, with a peak following the second half of the $19^{\text {th }}$ century and into the beginning of the $20^{\text {th }}$. Production declined very rapidly, for well-known political reasons, after 1949, but has continued discreetly, including during the Cultural Revolution, as is attested by several examples that were "saved from the deluge." The liberalization of the 1980s naturally coincided with renewed production. At present, a number of sculptors - notably in the Xinhua district - have reopened their workshops in order to meet the pressing demand for new bright and shiny statuettes. ${ }^{16}$

\section{Divinities and Men}

Before getting into the details on the specific individuals represented by the statuettes, we

\footnotetext{
${ }^{16}$ On this subject see Michela Bussotti, "Hunan zhongbu diqu "Jiating diaoxiang” de lüeshu."
} 
should emphasize that we are in the presence of a statuary for a household cult. Consecrations are rarely of the "communal" type, carried out by persons of different families (see Tables 2 and 3). The relatively small size of the statuettes - most often around $20 \mathrm{~cm}$ tall - and the indications, albeit unsystematic, that they were installed in the family altar for its protection (zuozhen jiatang 座鎮家堂, jiatang gongfeng 家堂供奉, zuozheng jiatang 坐正家堂, etc.) confirm that we are dealing with a domestic statuary. However, we can surmise that the larger statues - measuring between several dozen $\mathrm{cm}$ to over one metre tall — especially those in the $\mathrm{MH}$ collection, were destined for temples, and, in spite of the absence of written information, they would have required more space than that allowed in a domestic altar which, if we rely on contemporary observations, contains one or several niches rarely less than $20 \mathrm{~cm} \mathrm{high.}{ }^{17}$

The categories we have chosen do not claim to detail the process leading to the cult of a specific individual - whether it is an ahistorical deity, a nature cult, or a deified historical figure - nor do they identify the original status of the figure (celebrity, unnatural death, etc.), whether the cult was officially recognized or not, or whether it is a divinity associated with a specific social group (patron saint of a guild). The categories employed in this study are simply based on the fact that a "national" cult can be observed throughout China, even if this cult has historical and regional variations; that the territory of a "local" cult is limited to a part of China, be it transregional, regional, or strictly local. In the latter case, a local cult may very well overlap with an ancestral cult: ancestor in one family, he becomes a local deity in another; in the same manner, a master can be the direct master of an initiate and the ancestral master of a religious lineage for another. ${ }^{18}$ In other words, the categories chosen are operational in the context of an albeit simplified description of the religious situation of a specific region from the 18th century to the early 20th century-from a synchronic perspective, since deities of all categories could be found on the altars of the sponsors. This is not a hagiography, but rather a picture of the cults.

\subsection{National Divinities}

The number of statuettes of national pantheon divinities is relatively important, on the order of $20 \%$ in the two collections. Despite this common characteristic, the two collections nevertheless reveal remarkable differences. Taken as a whole, the PF collection contains a greater number of "Daoist" divinities than the MH collection, which, inversely, is remarkable for the predominance of Buddhist divinities (see Tables 2 and 3).

Table 2: Statuettes of national divinities in the PF collection

\begin{tabular}{|c|c|c|c|}
\hline Name of divinities & Number & $\begin{array}{c}\text { Familial } \\
\text { consecration }\end{array}$ & $\begin{array}{c}\text { Communitarian } \\
\text { consecration }\end{array}$ \\
\hline
\end{tabular}

\footnotetext{
${ }^{17}$ For a typology of domestic altars, see Feng Yunxing, "Fengjia shan jumin shenkan wenhua diaocha." Field research conducted in Hunan in 2003 revealed an altar containing large-scale deity statues, paid from communal fundraising, but we can wonder if this represents a past custom or if it is an exception resulting to the near disappearance of temples in Hunan.

${ }^{18}$ We will see further below that distinctions can be made thanks to the names used by sponsors to designate them.
} 


\begin{tabular}{|c|c|c|c|}
\hline $\begin{array}{l}\text { The God and Goddess of the Prefecture } \\
\text { of Destinies of the Eastern Kitchen of the } \\
\text { Nine Heavens } \\
\text { 九天東厨司命府君張冶相公(張單字梓 } \\
\text { 郭), 李氏夫人(玉池夫人) } \\
\text { (3) }\end{array}$ & 42 & 39 & \\
\hline $\begin{array}{l}\text { Lu Ban, god of carpenters } \\
\text { 魯班仙師 } \\
\text { (-587?)生期定公二年甲戌歲十二月井 } \\
\text { 午時日 (T0210) } \\
\text { (-587)生於定宮(公)三年甲戌歲十二月 } \\
\text { 廿一日午時生五月初七日申時得 } \\
\text { 五尺墨斗大神 } \\
\text { (5) }\end{array}$ & 20 & 15 & \\
\hline $\begin{array}{l}\text { King of Medicine } \\
\text { 藥王 (孫公真君, 孫真人) } \\
\text { (2) }\end{array}$ & 13 & 10 & 1 \\
\hline $\begin{array}{l}\text { God of the Southern Peak } \\
\text { 南嶽聖帝 }\end{array}$ & 11 & 11 & \\
\hline $\begin{array}{l}\text { Bodhisattva of Compassion } \\
\text { 南無救苦難靈感觀世音菩薩, 觀音大士 } \\
\text { (1) }\end{array}$ & 7 & 6 & \\
\hline $\begin{array}{l}\text { Guan Yu } \\
\text { 關聖帝君 }\end{array}$ & 6 & 6 & \\
\hline $\begin{array}{l}\text { Marshal Zhao } \\
\text { 趙公元帥 } \\
\text { (1) }\end{array}$ & 5 & 4 & \\
\hline $\begin{array}{l}\text { God of Earth } \\
\text { 中宮土地 (土地公) } \\
\text { (3) }\end{array}$ & 4 & 1 & \\
\hline $\begin{array}{l}\text { Great emperor of Thunder } \\
\text { 雷公大帝 } \\
\text { 普化天尊雷神大將佛* } \\
\text { 雷祖大帝* }\end{array}$ & 3 & 3 & \\
\hline $\begin{array}{l}\text { The Supreme Lord Lao } \\
\text { 太上老君 } \\
\text { (1) }\end{array}$ & 2 & 1 & \\
\hline $\begin{array}{l}\text { The Great Emperor of the Authentic } \\
\text { Martial Virtue }\end{array}$ & 2 & Missing & \\
\hline
\end{tabular}


12 Journal of Chinese Religions

\begin{tabular}{|c|c|c|c|}
\hline $\begin{array}{l}\text { 真武大帝 } \\
\text { (1) }\end{array}$ & & & \\
\hline $\begin{array}{l}\text { Hua Tuo } \\
\text { 華佗(陀) }\end{array}$ & 2 & 2 & \\
\hline $\begin{array}{l}\text { Patriarch Buddha of the Heavens? } \\
\text { 諸天佛祖 }\end{array}$ & 2 & 2 & \\
\hline $\begin{array}{l}\text { Jade emperor } \\
\text { 玉皇大帝 }\end{array}$ & 1 & 1 & \\
\hline $\begin{array}{l}\text { Great Inspector Emperor of Dongling? } \\
\text { 東陵觀鑑察大帝 }\end{array}$ & 1 & 1 & \\
\hline $\begin{array}{l}\text { Great Emperor of the Five Saintly } \\
\text { Officials? } \\
\text { [五]皇上聖靈官大帝 }\end{array}$ & 1 & & 1 \\
\hline $\begin{array}{l}\text { Great Emperor and Official of the Five } \\
\text { Numinous Manifestations and Seven } \\
\text { Jewels of the Smithy } \\
\text { 爐頭七寶五顯靈官大帝 }\end{array}$ & 1 & 1 & \\
\hline $\begin{array}{l}\text { Great Emperor of the } \mathrm{Ox} \\
\text { 牛(皇)大帝 }\end{array}$ & 1 & 1 & \\
\hline $\begin{array}{l}\text { Great Emperor and Master Patriarch } \\
\text { 祖師大帝 }\end{array}$ & 1 & 1 & \\
\hline $\begin{array}{l}\text { Great Emperor and Second Grade } \\
\text { Immortal Official of the Middle Origin } \\
\text { 中元二品仙官大帝 }\end{array}$ & 1 & 1 & \\
\hline King of the Five Sacred Peaks 五岳朝王 & 1 & 1 & \\
\hline $\begin{array}{l}\text { Guan Ping } \\
\text { 關平 } \\
\text { (1) }\end{array}$ & 1 & & \\
\hline $\begin{array}{l}\text { Third Marshal and Venerable Master of } \\
\text { Exorcism or The Three marshals and } \\
\text { Venerable Masters of Exorcism? } \\
\text { 法主尊師三元師 }\end{array}$ & 1 & 1 & \\
\hline $\begin{array}{l}\text { Celestial Lord Wang } \\
\text { 王公天君 }\end{array}$ & 1 & 1 & \\
\hline $\begin{array}{l}\text { General Liu Meng } \\
\text { 劉[猛]將軍 }\end{array}$ & 1 & 1 & \\
\hline $\begin{array}{l}\text { Meng the Great Protector and Perfected } \\
\text { One }\end{array}$ & 1 & 1 & \\
\hline
\end{tabular}

${ }^{19}$ This may be the Great Emperor of the Perfected Martial Virtue 真武大帝. 


\begin{tabular}{|c|c|c|c|}
\hline 孟公太尉真人 & & & \\
\hline $\begin{array}{l}\text { King of the Peak? } ?^{20} \\
\text { 岳王 }\end{array}$ & 1 & 1 & \\
\hline $\begin{array}{l}\text { The Second Saintly Celestial Concubine } \\
\text { 天妃大聖二娘 }\end{array}$ & 1 & 1 & \\
\hline $\begin{array}{l}\text { Numinous Snake and Crocodile King } \\
\text { 蛇鱏灵王[菩]薩 }\end{array}$ & 1 & 1 & \\
\hline $\begin{array}{l}\text { Numinous King of Good and Evil } \\
\text { 善惡靈王 }\end{array}$ & 1 & Missing & \\
\hline $\begin{array}{l}\text { Dipamkara } \\
\text { 華光[烟]佛 }\end{array}$ & 1 & 1 & \\
\hline $\begin{array}{l}\text { Zhang Daoling } \\
\text { 張道陵 } \\
\text { (1) }\end{array}$ & 1 & & \\
\hline $\begin{array}{l}\text { Pu'an } \\
\text { 普庵 }\end{array}$ & 1 & 1 & \\
\hline $\begin{array}{l}\text { Perfected Lord Erlang } \\
\text { 二郎真君 }\end{array}$ & 1 & 1 & \\
\hline $\begin{array}{l}\text { Immortal Lord Xu Xun } \\
\text { 許[遜](仙)君 }\end{array}$ & 1 & 1 & \\
\hline $\begin{array}{l}\text { Sun Bing the Perfected One } \\
\text { 孫臏真人 }\end{array}$ & 1 & 1 & \\
\hline $\begin{array}{l}\text { Li the Immortal Perfected One } \\
\text { 李仙真人 }\end{array}$ & 1 & & 1 \\
\hline $\begin{array}{l}\text { Wang the Immortal Perfected One } \\
\text { 汪仙真人 }\end{array}$ & 1 & & 1 \\
\hline Total & 144 & 117 & 5 \\
\hline
\end{tabular}

Table 3: Statuettes of national divinities in the MH collection

\begin{tabular}{|c|c|c|c|}
\hline Name of divinities & Number & $\begin{array}{c}\text { Familial } \\
\text { consecration }\end{array}$ & $\begin{array}{c}\text { Communitarian } \\
\text { consecration }\end{array}$ \\
\hline $\begin{array}{l}\text { Bodhisattva of Compassion Guanyin } \\
\text { 南無救苦救難觀世音,觀音大土 } \\
(65)\end{array}$ & 80 & 15 & \\
\hline $\begin{array}{l}\text { Sovereign Lord Guan Yu } \\
\text { 關聖帝君 } \\
\text { 關聖帝君 } \\
\text { (31) }\end{array}$ & 44 & 11 & \\
\hline
\end{tabular}

${ }^{20}$ The iconography of this statuette looks like the God of Medicine. 
14 Journal of Chinese Religions

\begin{tabular}{|c|c|c|c|}
\hline $\begin{array}{l}\text { God of the Southern Peak } \\
\text { 南訔聖帝 } \\
\text { (9) }\end{array}$ & 14 & 1 & \\
\hline $\begin{array}{l}\text { Guanyin the Bodhisattva of } \\
\text { Compassion for Having Babies } \\
\text { 送子觀音 } \\
\text { (12) }\end{array}$ & 13 & 1 & \\
\hline $\begin{array}{l}\text { Celestial Lord Wang } \\
\text { 王公天君(王公元帥) } \\
\text { (7) }\end{array}$ & 11 & 4 & \\
\hline $\begin{array}{l}\text { Luo Han } \\
\text { 羅漢 } \\
(7)\end{array}$ & 10 & 1 & \\
\hline $\begin{array}{l}\text { Amitaba } \\
\text { 南無阿弥陀佛 } \\
\text { (6) }\end{array}$ & 7 & 1 & \\
\hline $\begin{array}{l}\text { King of Medicine (Sun the Perfected } \\
\text { One) } \\
\text { 藥王(孫公真人) } \\
\text { (3) }\end{array}$ & 6 & 3 & \\
\hline $\begin{array}{l}\text { God of Wealth } \\
\text { 財神菩薩 } \\
\text { (4) }\end{array}$ & 5 & 1 & \\
\hline $\begin{array}{l}\text { Grand Emperor of Authentic Martial } \\
\text { Virtue / [Great Emperor of] the } \\
\text { Mysterious Northern Heaven of } \\
\text { Authentic Martial Virtue } \\
\text { 真武大帝 } \\
\text { 北方真武玄天[大 ][帝] } \\
\text { (2) }\end{array}$ & 4 & 2 & \\
\hline $\begin{array}{l}\text { Heavenly Venerable of Universal } \\
\text { Transformation } \\
\text { 普化天尊 } \\
\text { (3) }\end{array}$ & 4 & & \\
\hline $\begin{array}{l}\text { Yama } \\
\text { 漢君羅王 } \\
\text { 焰摩尊天 } \\
\text { (1) }\end{array}$ & 3 & 2 & \\
\hline $\begin{array}{l}\text { Heavens? } \\
\text { 諸天 }\end{array}$ & 2 & 1 & \\
\hline
\end{tabular}




\begin{tabular}{|l|c|c|c|}
\hline $\begin{array}{l}\text { Marshal Zhao } \\
\text { 趙元帅 }\end{array}$ & 2 & 1 & \\
\hline $\begin{array}{l}\text { Sakyamuni } \\
\text { 释迦牟尼 } \\
(1)\end{array}$ & 2 & 1 & \\
\hline $\begin{array}{l}\text { Bodhisattva } \\
\text { 菩薩 } \\
(1)\end{array}$ & 2 & & \\
\hline $\begin{array}{l}\text { Patriarch Hua Tuo } \\
\text { 華陀祖師 }\end{array}$ & 1 & & \\
\hline $\begin{array}{l}\text { Emperor Lord of the Sacred Peaks } \\
\text { 岳王帝主 }\end{array}$ & 1 & & \\
\hline $\begin{array}{l}\text { Left Assistant of the Passes of } \\
\text { Inspection [of fate]? } \\
\text { 左都督關 }\end{array}$ & 1 & 1 & 1 \\
\hline $\begin{array}{l}\text { Hegemon of Rivers } \\
\text { 鎮江王爺 }\end{array}$ & 1 & 1 & \\
\hline $\begin{array}{l}\text { Zhang the Perfected One } \\
\text { 張真人 }\end{array}$ & 1 & 1 & 1 \\
\hline $\begin{array}{l}\text { Lord Zhang the God of the Kitchen } \\
\text { 張相公 }\end{array}$ & 1 & & \\
\hline $\begin{array}{l}\text { King Yang Si } \\
\text { 楊泗王爺 }\end{array}$ & 1 & & \\
\hline $\begin{array}{l}\text { Manjusri } \\
\text { 文殊菩薩 }\end{array}$ & 1 & & \\
\hline $\begin{array}{l}\text { Imperial Mother of Heavenly } \\
\text { Immortals } \\
\text { 天仙皇母 }\end{array}$ & 1 & \\
\hline $\begin{array}{l}\text { Bodhisattva of the Evil Serpents? } \\
\text { 蛇恶菩薩 }\end{array}$ & 1 & \\
\hline $\begin{array}{l}\text { Great Emperor of Purple Subtlety, } \\
\text { Celestial Official of the First Grade } \\
\text { Who Confers Blessings } \\
\text { 上元一品天官賜福紫微大帝 }\end{array}$ & 1 & \\
\hline $\begin{array}{l}\text { Judge of the Department of Destinies } \\
\text { 判官佐司 }\end{array}$ & 1 & \\
\hline $\begin{array}{l}\text { Venerable Judge? } \\
\text { 判官[天]尊 }\end{array}$ & 1 & \\
\hline
\end{tabular}




\begin{tabular}{|l|c|l|l|}
\hline $\begin{array}{l}\text { Marshal Ma } \\
\text { 馬元帥 }\end{array}$ & 1 & 1 & \\
\hline $\begin{array}{l}\text { Venerable..emperor? } \\
\text { 帝[]尊[天] }\end{array}$ & 1 & & \\
\hline $\begin{array}{l}\text { Vaisravana, Guardian of the North } \\
\text { 多聞天王 }\end{array}$ & 1 & & \\
\hline $\begin{array}{l}\text { Dhrtarastra, Guardian of the East } \\
\text { 持國天王 }\end{array}$ & 1 & & \\
\hline $\begin{array}{l}\text { Celestial King } \\
\text { 天王 }\end{array}$ & 1 & & \\
\hline $\begin{array}{l}\text { Guan Ping } \\
\text { 關平 } \\
\text { (1) }\end{array}$ & 1 & & \\
\hline $\begin{array}{l}\text { God of the Earth } \\
\text { 土地公 } \\
\text { (1) }\end{array}$ & $\mathbf{1 5 3}$ & $\mathbf{5 0}$ & $\mathbf{5}$ \\
\hline Total & & & \\
\hline
\end{tabular}

(number): number of divinities whose identity deduced based on iconography

The conditions and drive behind the collector's impulse can tip the balance to favor one type of statue over another. The PF collection is the product of a collector well-versed in Daoist studies, who took the time to get to know and appreciate the statuettes on sale in antiques markets of Peking over a ten year period. The MH collection was born under very different circumstances. Stacked in wooden crates and seized by customs officials in Changsha in 1984, they were intended for sale on foreign art markets, starting with that of Hong Kong. No doubt the sender, who was convicted for this attempt to illegally export Chinese patrimony, was primarily motivated by the lure of rapid gain with relatively large sized statues. Consciously or not, he must have had in mind lovers of Buddhist art, which generally enjoyed a reputation and an interest greater than that of Daoist art, which was still poorly known. ${ }^{21}$ Notwithstanding the vagaries of collecting, taken together the two collections allow us to have a more balanced and precise idea of the nature and production of statuettes in central Hunan and, consequently, of the religious situation in the region.

Classified by the number of instances (see Table 2), the divinities who occupy the first seven places in the PF collection are, in order, Zaowang 䆮王, Lu Ban 魯班, Yaowang 藥王, Nanyue shengdi 南嶽聖帝, Guanyin 觀音, Guangong 關公, Zhao yuanshuai 趙元帥.

What could be more natural than that the Kitchen God, and his wife, whose role is to watch over the affairs of the family, figures into the highest rank of the domestic statuary (Pl. 6)? The name is stated as Jiutian dongchu siming fu jun 九天東廚司命府君, the Lord of the

${ }^{21}$ The first great international exhibition on Taoist Art was held in Chicago in 2000. See Little \& Eichman, Taoism and the Arts of China. 
Prefecture Director of Destiny of the Eastern Kitchen of the Nine Heavens; sometimes abbreviated so as only to retain their principal role: the director of destiny (siming 司命). The civil name of the gentleman, Zhang Ye 張冶, as well as that of his wife, Li shi furen 李氏夫人, are mentioned. Sometimes the gentleman's name is given in its entirety: Zhang, personal name Dan 單, with the designation Ziguo 子郭 or Ziguo 梓郭. Traditionally, families paid particular attention to these gods installed in the house, notably when, several days before the New Year, they had to go to the Celestial Court to present a tally of the good deeds-but also the bad ones - committed by members of the family. The vows or intentions set out in the consecration certificates are generally vague:

侍奉長生香炳, 求保人丁清吉, 六畜興肥, 百事吉祥, 万般如意, 凡在光中, 全 叨庇佑。

Holding the incense of longevity, I implore Your protection so that men may be at peace, the domestic animals fat, business good, that everything is accomplished according to our wishes, and that in a general manner all that is found under the light be protected.

These propitiatory formulas, which sometimes conceal the true and concrete motivations, take a more precise turn when addressed to the Kitchen God. One might ask that their father or son recover from an illness, or they might seek longevity for their grandmother. In the twelve concrete cases, occular ailments are invoked three times. For a boy who, in 1877, was a year old and suffered from multiple illnesses and difficulties, a vow ( $x$ yuan 許愿) was pronounced before the god. A number of years later, in 1882, when the wish had been granted, the act of return of grace (huan yuan 還愿) was done, consisting of the sculpting of a new statue in the form of the god in order to repay his good deeds. 


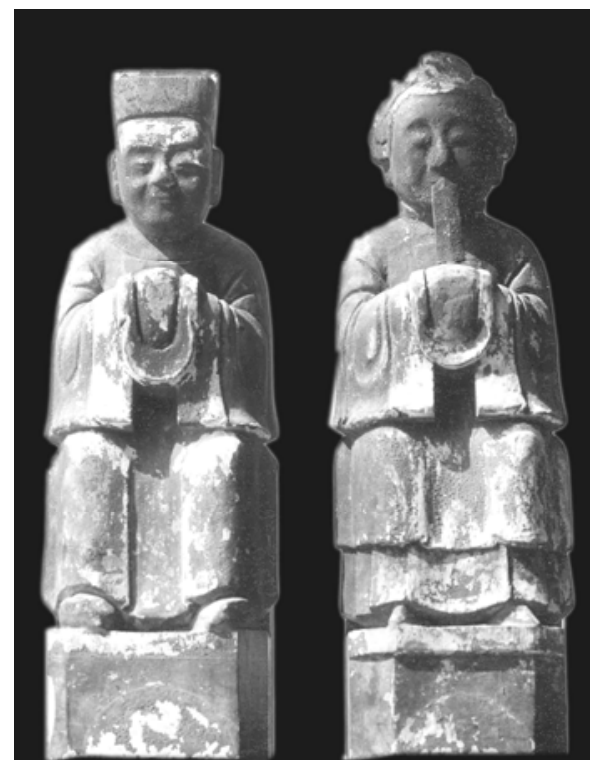

P1. 6: The god [left] and the goddess [right] of the kitchen, Ningxiang?, 1929,

h. $23.6 \mathrm{~cm}, \mathrm{~T} 1031$

Cliche Claude Delhaye CEFEO

With Lu Ban and the Medicine God, we are dealing with professionals (Pl. 7). Lu Ban, protector of all the guilds relating to construction (carpenters, cabinetmakers, roofers, bridge and boat builders, etc.) and for this reason also designated by the name Great Divinity of the Ink-Cup Marker and the Five-Foot Ruler (Wuchi modou dashen 五尺墨斗大神), is said to have been born in 587 B.C (T0305). One asks him to ensure that the craft (shouyi 手藝) be profitable; one presents oneself as a woodworker (mujiang 木匠) or a journeyman (gongshi 工師), but this would be to forget that these guilds equally imply a religious formation. The disciples studied the orthodox doctrine of $\mathrm{Lu}$ Ban ( $\mathrm{Lu}$ Ban zhengjiao 魯班正教), the secret formulas (fajue 法訣), talismans ( $f u f a$ 符法) and the use of lustrous water; they were accepted and initiated by the masters to whom they paid homage. To enter into the guild was also to enter into a religious lineage. ${ }^{22}$ It did not suffice to learn construction methods, it was necessary to also know how to chose the place and to determine the propitious proportions of a new house, to complete the necessary rites to cut and hew the wood, place the top beamsthe critical moment of construction — and, possibly, exorcise living spaces.

\footnotetext{
${ }^{22}$ See Feng Wangxing, "Lu Ban shu zai banwu jianzhu ji richang shenghuo zhong de yunyong," 908-921.
} 


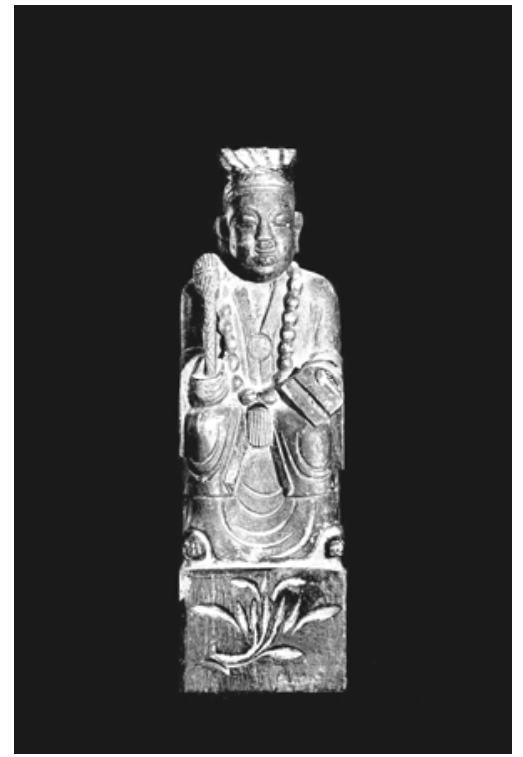

Pl. 7: Lu Ban, Ningxiang?, 1983, h. $25.6 \mathrm{~cm}$, T0618

Cliche Zhang Chaoyin OEFEO

Represented by the tiger and the dragon that he healed, the Medicine God, Yaowang 藥王 (Pl. 8), alias Sun Simiao 孫思邀, or simply Sun Zhenren 孫真人, ${ }^{23}$ was part of the thirteenth generation of doctors, among whom are found Shennong 神農, Leigong 雷公, Wang Shuhe 王叔和, Zhang Zhongjing 張仲景, the prince of Mount Xue 雪山太子 (?), all the monks, patriarchs, and Daoists . . finally arriving at the local divinity Zhang Wulang 張五郎, then to the founder of the lineage (qijiao 啟教), Yang Falong 楊法龍 (T0185). Thus are inscribed a good thirty names, the masters belonging to this line, listed individually on the paper as one does during rituals of invitation of divinities, an obligatory and oft-repeated exercise. The disciples, who unlike the others do not carry the distinctive stamp of the master of rituals (i.e., an ordination name with $f a$ ), naturally have many reasons to invoke Yaowang: because they themselves have entered into the orthodox doctrine of Yaowang (Yaowang zhengjiao 藥王正 教), or, more simply, because they have moved and opened a new medicinal plants shop. Hua Tuo 華佗 (Pl. 9), renowned doctor of the end of the Han and beginning of the Three Kingdoms, executed by the King of Wei because had suggested trepanation to heal the king's headaches, is also present on the altar of the masters of the art, but to a lesser degree. He seems to have been favored by healers who used water and talismans (shuishi 水師) in their therapies. ${ }^{24}$ As with the preceding disciple of Yaowang, the disciple Jiang Youqing 姜佑卿,

\footnotetext{
${ }^{23}$ Concerning the God of Medicine, see Unschuld, Medicine in China, 88-94, and Fang Ling, Une tradition sacrée de la médecine chinoise ancienne.

${ }^{24}$ A manuscript text used for the initiation (benjing 本經) of a healer from Lengshui jiang often
} 


\section{Journal of Chinese Religions}

initiation name Famao 法茂, in 1892 records the list of the masters of his lineage in Anhua district, who, after eleven names, mentions an ancestral master (shizu 師祖), a grand master (shitai 師太), a master (shigong 師公), then finally his initiation master (dushi 度師) Jiang Faming 姜法鳴, having taken care to indicate the dates of birth of each of these (T0700). We here have 15 names, including the sponsor's. If we assume that this is a genealogy of masters, the founder would have lived about 400 years earlier, i.e around 1500. The terms shizu, shitai and shigong would thus represent the "great grandfather", the "grandfather" and the "father" of the initiation master, knowing that the great grandfather and grandfather do not carry the surname Jiang. ${ }^{25}$

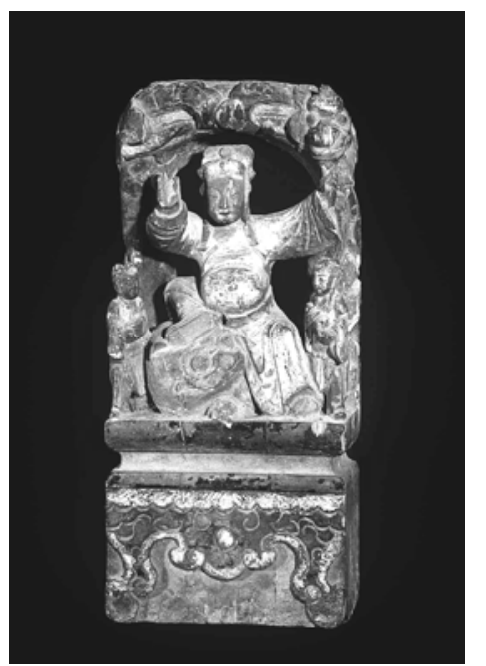

P1. 8: Yaowang (God of Medicine), Xiangtan, Qing dynasty, h. $33.6 \mathrm{~cm}$, T0185 Cliche Zhang Chaoyin OEFEO

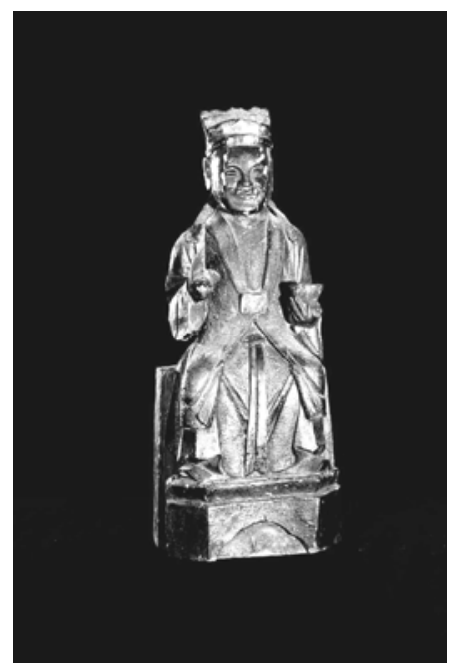

Pl. 9: Hua Tuo, Ningxiang, 1892, h. $22 \mathrm{~cm}, \mathrm{~T} 0604$

Cliche Zhang Chaoyin CEFEO

makes reference to Hua Tuo in the ritual for invoking divinities and in talismans. Our thanks are warmly extended to Fang Ling, who brought to our attention this manuscript, which she obtained during field research in Hunan.

${ }^{25}$ See also pp. $45-46$. 


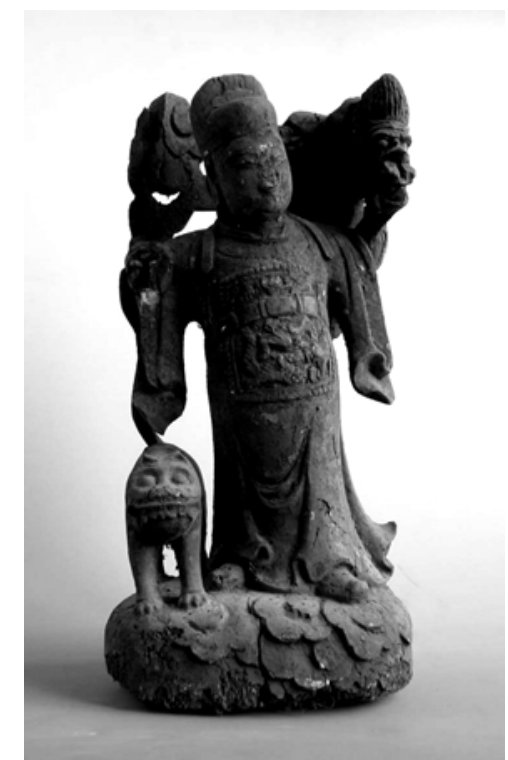

Pl. 10: Yaowang, h. $30.3 \mathrm{~cm}, 0828 / \mathrm{c}: 1719$

Cliche Hunan Museum CEFEO

Nanyue shengdi 南獄聖帝, the God of the Southern Peak, located on Hengshan in southeastern Hunan province, was de rigueur on familial altars (Pl. 11). One goes to the holy sites on pilgrimage to make or to deliver vows, or, for lack of a better option, to the local temple that is dependent on the mother temple. So it is that He Jiubin 賀就賓 went to Zhurong Peak 祝融峰, located on the summit of Hengshan and the final destination of all pilgrimages, on behalf of his mother who was afflicted with an eye malady (T0717). The wife of Liu Xingjie 刘星階 also suffered from a grave eye malady. Medicine changed nothing. It was only after she implored Nanyue shengdi and drank his miraculous tea that she finally recovered her sight (T0428). 


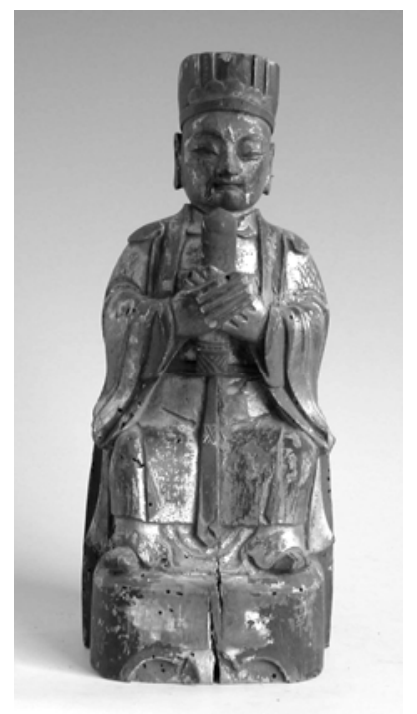

Pl. 11: The God of the Southern Peak, h. $23 \mathrm{~cm}, 0410 / \mathrm{C}: 1399$

Cliche Hunan Museum OEFEO

Guanyin 觀音, Guan Yu 關羽, Zhao Gongming 趙公明, under their multiple names of investiture, were also expected to receive the homage of the faithful. Guanyin, the compassionate one, is depicted carrying a child (songzi Guanyin 送子觀音) in the $\mathrm{MH}$ collection; Guan $\mathrm{Yu}$, the warrior and the protector, the ancestral Buddha and the Heavenly Venerable who Harmonizes and Subdues the Demons of the Three Realms (Sanjie fumo xietian datianzun 三界伏魔協天大天尊), is often with his adopted son Guan Ping 關平, the carrier of the seal; Zhao Gongming, the God of Wealth in his martial or lettered version, is one of the four grand marshals of celestial troops (with Wang 王, Ma 馬, and Yin 殷) and is one of the most frequently invoked deities in the rituals of the region. Many others respond to the roll-call: the Jade Emperor, the God of Thunder (Leishen 雷神), Laozi in his deified form, other celestial marshals (Wang tianjun 王天君), one or two female divinities and some unknowns like Dongling guan jiancha dadi 東陵觀鑑察大帝. One of these, the Grand Emperor of the Smithy (Lutou qibao wuxian lingguan dadi 爐頭七寶五顯靈官大帝) (Pl. 12), is incontestably the patron of the guild of metal-workers, whether forgers, minters, or those who worked with iron, bronze, silver or gold. ${ }^{26}$ As with Lu Ban and Yaowang, it was a disciple, answering to the name Zuo Gansheng 左幹生 and newly ordained by his master, who installed it on his altar in 1906 (T0522).

\footnotetext{
${ }^{26}$ Concerning this corporation and his religious practices, see Liu Guozhong, Tang Haochu, "Lengshui jiang, Xinhua jinshu jiagong gongjiang xinyang xisu diaocha," 778-797.
} 


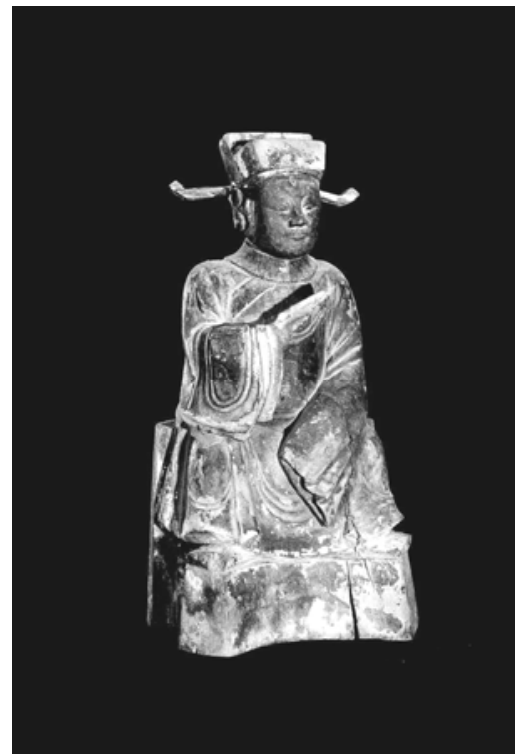

Pl. 12: The God of the Smithy (Lutou qibao wuxian lingguan dadi), Ningxiang?, 1906, h. $23.5 \mathrm{~cm}, \mathrm{~T} 0522$

Cliche Zhang Chaoyin CEFEO

As we indicated earlier (see Table 3), the Buddhist deities in the MH collection, the Guanyins, Luohans and other Amitabhas, are clearly more numerous than the divinities of the other pantheons. Nonetheless, the top 10 are Nanyue (pl. 12), a celestial marshal (Wang yuanshuai 王元帥) and Yaowang (pl. 10). In other words, the presence of certain divinities is confirmed, despite the difference in the conditions and the constitution of the collection. To close this panorama of divinities, I would like to evoke the few communitarian cults that emerge from study of the two collections. In general, the statuettes commissioned by devotees with different family names, gathering people who, in most cases, if not from the same neighborhoods, are at least from the same locale, are of a larger size -- in the vicinity of 40-50 $\mathrm{cm}$-- than the average of the "domestic" statuettes. In the PF collection, we have a statue of Yaowang, of Wuhuang shangsheng lingguan dadi 五皇上聖靈官大帝; in the MH collection, a statuette of Zuodu duguan 左都督關, Panguan zuosi 判官佐司, Panguan [ ] zun 判官[ ] 尊. The identity of the latter remains to be determined, but he clearly occupied the office of inspector or judge - those who send the dead to hell or to paradise — generally associated with the God of the City (Chenghuang 城隍), or the God of the Eastern Peak (Dongyue dadi 東获 大帝). Nonetheless, a commonality exists between the two collections and concerns the cult for the immortals: Li xian zhenren 李仙真人 (Pl. 13) and Wang xian zhenren 汪仙真人 (Pl. 14) commissioned by the same donors in the PF collection, ${ }^{27}$ and Zhang zhenren 張真人 (Pl.

${ }^{27}$ It seems that Li and Wang belong, with Pan 潘, to the Three female immortals who were born in 
24 Journal of Chinese Religions

15) for the MH collection.

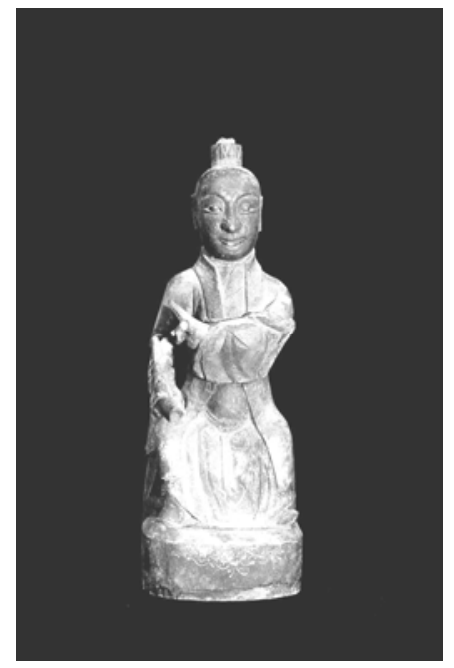

Pl. 13: Wang xian zhenren, Yiyang, 1936, h. $24.6 \mathrm{~cm}, \mathrm{~T} 0689$ Cliche Zhang Chaoyin CEFEO

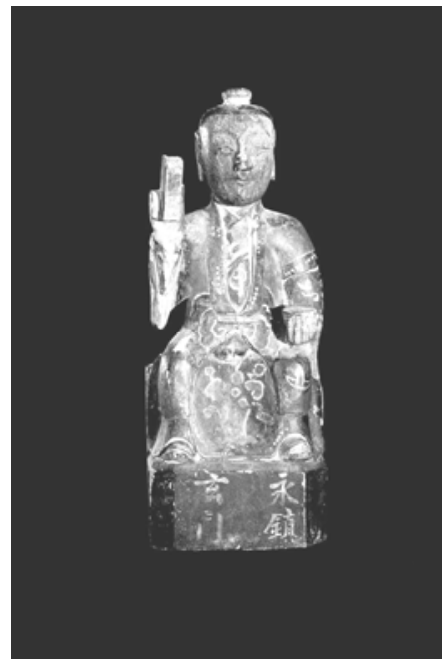

Pl. 14: Li xian zhenren, Yiyang, 1936, h. $27.2 \mathrm{~cm}$, T0702

Cliche Zhang Chaoyin OEFEO

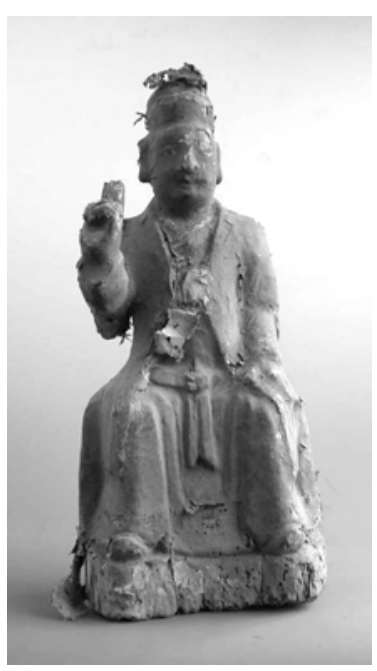

Pl. 15: Zhang zhenren, Shaoyang, 1836, h. $40.5 \mathrm{~cm}, 0741 / \mathrm{C}: 1627$

Cliche Hunan Museum OEFEO

the Song dynasty and who went to live at a mountain in Xinhua, where they meet Tong jun Yilang 童君 一郎. See Wu Qiming, “Qingxu dao si xianzhen diaocha baogao,” 108-138. 


\subsection{Local Deities, Ancestors and Masters}

The distinction between local deities, ancestors and masters is not an easy one to establish. With the exception of certain local deities recognized as such, for example Zhang Wulang, ${ }^{28}$ some local deities are also ancestors for a family, or masters of a specific initiation lineage and masters can also be ancestors and ancestors can be masters. Nonetheless, we can determine the nature of the cult on the basis of the name used by the sponsor to designate the statue, as well as the existence of several statues of the same individual who was the object of extralineage cults in different localities, or on the basis of the title used in the name of the statuette, and other criteria that will be discussed below. To begin, using the consecration certificate which, besides the dates of consecration, sometimes provides the dates of birth of the individual being worshipped, we will analyze the data, in which there is virtually no distinction between local divinities, ancestors and masters. (see Table 4).

Table 4: Dates of birth of represented individuals according to location (PF collection)

\begin{tabular}{|c|c|c|c|c|c|c|c|c|c|c|c|}
\hline No & Date & $\begin{array}{c}\text { Anhua } \\
\text { 安化 }\end{array}$ & $\begin{array}{c}\text { 新化 } \\
\text { 益陽 }\end{array}$ & $\begin{array}{c}\text { Xiangxiang } \\
\text { 泪鄉 }\end{array}$ & $\begin{array}{c}\text { Shaoyang } \\
\text { 召陽 }\end{array}$ & $\begin{array}{c}\text { Ningxiang } \\
\text { 寧鄉 }\end{array}$ & $\begin{array}{c}\text { Longhui } \\
\text { 隆回 }\end{array}$ & $\begin{array}{c}\text { Origin } \\
\text { uncertain }\end{array}$ & $\begin{array}{c}\text { Without } \\
\text { address }\end{array}$ & Total \\
\hline T0839 & 1144 & & & & & & & & & & $\mathbf{1}$ \\
\hline T0459 & $1288 / 1348$ & 1 & & & & & & & & & $\mathbf{1}$ \\
\hline T0295 & $1370 ?$ & 1 & & & & & & & & & $\mathbf{1}$ \\
\hline T0765 & 1384 & 1 & & & & & & & & & $\mathbf{1}$ \\
\hline T0373 & 1422 & & & & & 1 & & & & & $\mathbf{1}$ \\
\hline T0146 & $1485 ?$ & 1 & & & & & & & & & $\mathbf{1}$ \\
\hline T0390 & 1531 & & 1 & & & & & & & & $\mathbf{1}$ \\
\hline T0010 & $1574 ?$ & & 1 & & & & & & & & $\mathbf{1}$ \\
\hline & 1576 & & 2 & & & & & & & & $\mathbf{2}$ \\
\hline & $1620-1630$ & 3 & & & & & & & & & $\mathbf{3}$ \\
\hline T0406 & $1646 ?$ & & & & & 1 & & & & & $\mathbf{1}$ \\
\hline & 1652 & 1 & 1 & & & & & & & & $\mathbf{2}$ \\
\hline & $1680-1689$ & 3 & & & & & & & & 1 & $\mathbf{4}$ \\
\hline & $1690-1699$ & & & 1 & & & 1 & & & & $\mathbf{2}$ \\
\hline & $1700-1709$ & 1 & 1 & & & & & & & & $\mathbf{2}$ \\
\hline & $1710-1719$ & 1 & 1 & & & & 1 & & & & $\mathbf{3}$ \\
\hline & $1720-1729$ & 1 & 2 & & & & & & & 1 & $\mathbf{4}$ \\
\hline
\end{tabular}

${ }^{28}$ See below p. $29-30$. 
26 Journal of Chinese Religions

\begin{tabular}{|c|c|c|c|c|c|c|c|c|c|c|c|}
\hline & $1750-1759$ & 4 & & 2 & & & & & & & 6 \\
\hline & $1760-1769$ & 5 & 1 & & & & 2 & & & & 8 \\
\hline & $1770-1779$ & 1 & & 1 & & & & & & & 2 \\
\hline & $1780-1789$ & 4 & 2 & & 1 & & 1 & & & 2 & 10 \\
\hline & $1790-1799$ & 2 & & & 1 & & 1 & & & 2 & 6 \\
\hline & $1800-1809$ & 3 & 3 & & 1 & & 1 & & & 1 & 9 \\
\hline & $1810-1819$ & 6 & 2 & 1 & & & & & & & 9 \\
\hline & $1820-1829$ & 4 & 4 & 1 & & & 1 & 1 & 1(湖南) & 3 & 15 \\
\hline & $1830-1839$ & 2 & & 2 & 1 & & 2 & & $1 ?$ & 1 & 12 \\
\hline & $1840-1849$ & 4 & 3 & 1 & 2 & & 2 & & & 1 & 13 \\
\hline & $1850-1859$ & 6 & 1 & 2 & & & 3 & & 1(湖南) & 2 & 15 \\
\hline & $1860-1869$ & 4 & 1 & & 1 & & 2 & & $\begin{array}{c}1 \text { (湖南) } \\
1 \text { (湖南) } \\
1 ?\end{array}$ & 7 & 18 \\
\hline & $1870-1879$ & 2 & 4 & 2 & 2 & & 4 & 1 & $1 ?$ & 3 & 19 \\
\hline & $1880-1889$ & 3 & & 1 & & & 2 & & $\begin{array}{c}3 \text { (湖南) } \\
2 ?\end{array}$ & 1 & 11 \\
\hline & $1890-1899$ & 4 & 2 & 1 & 1 & 1 & 4 & & 1(湖南) & 2 & 16 \\
\hline & 1900-1909 & 2 & 1 & & 1 & & 1 & & & 2 & 7 \\
\hline & $1910-1925$ & & & & & & & & 1(湖南) & 1 & 2 \\
\hline T0042 & 1933 & & & & & & & & 1(湖南) & & 1 \\
\hline Total & & 73 & 34 & 15 & 11 & 3 & 28 & 2 & 15 & 32 & 213 \\
\hline
\end{tabular}




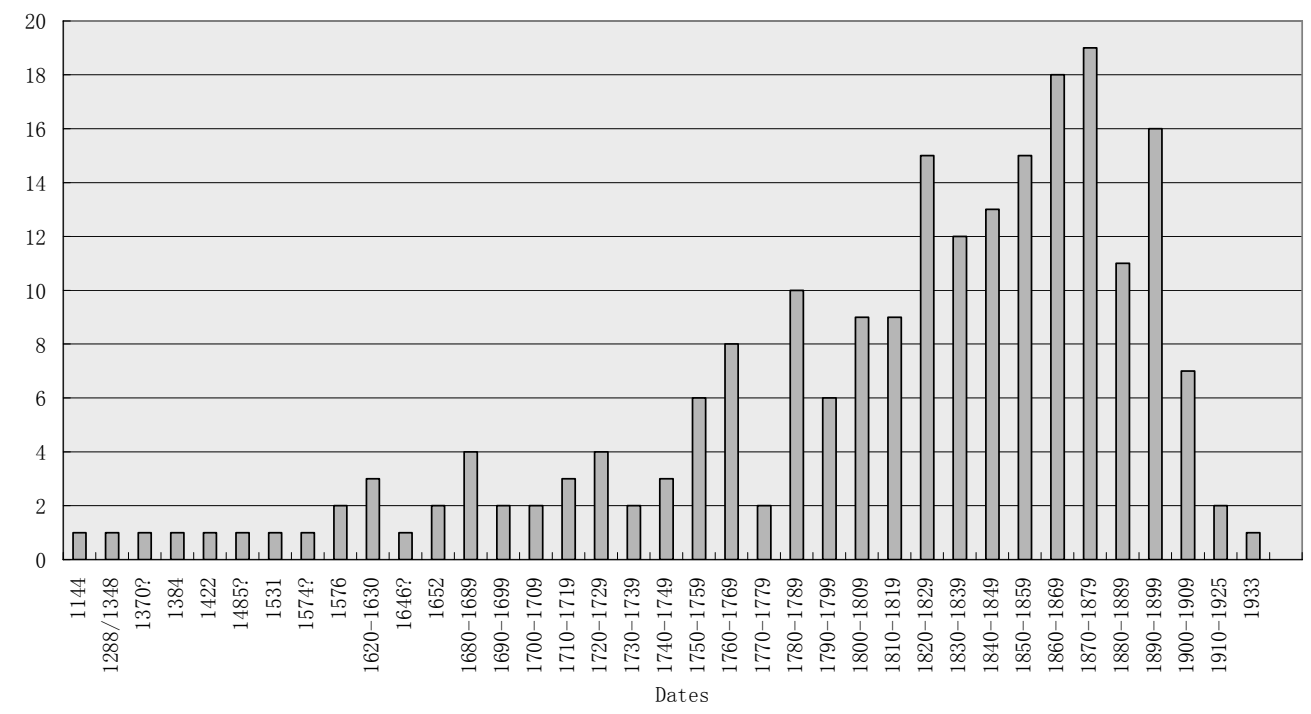

Graphic 2: Chronological Distribution of Statuettes According to Birthday

One Master Xia 夏君 was born in $1144,{ }^{29}$ at the hour $w u$ 午 of the sixth day of the fourth month. In 1946 his distant disciple, Wang Baiyun 王白雲, established a cult to him (T0839). Born under the Yuan, the grand ancestor (taizu 太祖) Shao Faxing 邵法興 (b. 1288?) was invoked by one of his descendants of the twentieth generation or so, along with the descendant's sons and a daughter-in-law, in order to intercede on behalf of the descendant's wife, née Liu, whose “body is not appeased” (shenti bu an 身體不安) (T0459). Less than a dozen individuals who lived under the Ming found themselves honored with a cult three or four centuries later. One of them, Wu Yongdao 吳永道 (P1. 16), has a very developed biography. Part of the seventh generation of Wus installed in Chang'an 常安 (in the canton of Chang'an in Anhua or the Chang'an north of Liuzhou 柳州, in the present-day province of Guangxi?), Yongdao came into being in the hour you 西 of the sixth day of the fourth month of the year 1485. He passed a studious youth and acquired a knowledge of rites, then took for his first wife a lady Kuang 匡 and for his second a lady née Li 李. During the Zhengde era (1506-1521), due to "disruptions caused by brigands", eighty ruffians attacked a village where they killed one member of the Wu's clan. Unable to tolerate this, Wu took leave of his father and mother, parted from his wives, assembled a band and dashed off in pursuit of the brigands. They caught up with them at Shuangjiangkou 雙江 $\square$ in Ningxiang district. During the battle, $\mathrm{Wu}$, always at the fore, was injured in the little village of Ma'ao, but managed to return

\footnotetext{
${ }^{29}$ Xia's name is incomplete: Xia jun [ ] [Long] 夏君 [ ][隆].
} 
nonetheless. With this epic episode behind him, the hero settled in Anhua where everyone praised his merit. The prefectural authorities recommended that he be inducted into the Imperial Hall of Golden Bells (Jinluan dian 金鑾殿), while an imperial decree conferred upon him an investiture and a memorial pavilion. In Ma'ao, a temple of Loyal Subjects (Zhongchen miao 忠臣廟) was established for him. His effigy was exposed during the spring and autumn sacrifices dedicated to the God of the Earth (she 社). Whether "summoning the wind and calling the rain," or, evidently, exterminating brigands and capturing thieves, as well as bringing sons and daughters, no task was too great for Wu Yongdao, the grand bodhisattva (pusa mohesha 菩薩摩荷沙, that is to say pusa mokesa 摩訶薩, bodhisattava mahasattva)!

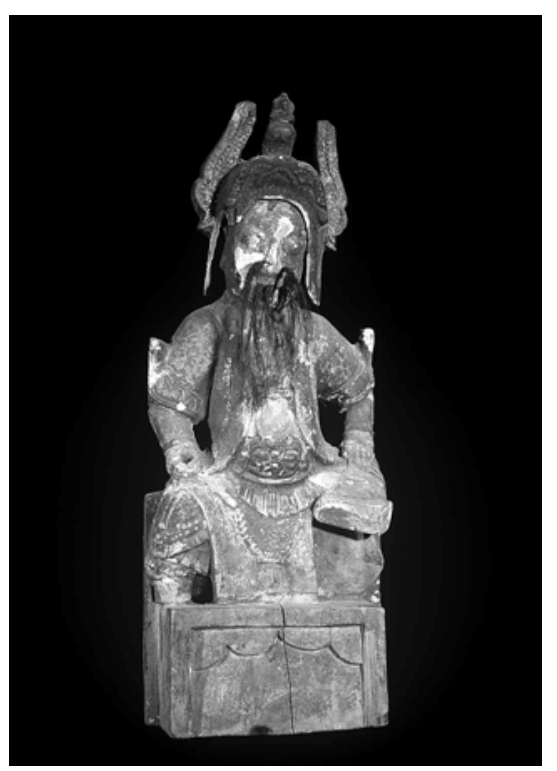

Pl. 16: Wu Yongdao (1485-?), Anhua, 1799 , h. $35 \mathrm{~cm}$, T0146

Cliche Zhang Chaoyin OEFEO

Apart from the brave and filial $\mathrm{Wu}$, the others are all masters of ritual, such as Zou Faling 鄒法靈, born in 1576. A statuette of him was commissioned at great expense by the Luo 羅 family of Xinhua in the 1870s and to whom Luo Shilin 羅世林, a medium (jiaoma 腳馬) of the family, asked that he "carry incense and fire in the ten regions" (shifang xingxiang zouhuo 十方行香走火), which is to say that in the four directions one could call upon his services (T0095).

Though one cannot rule out the possibility a priori, the antiquity of the birthdates obviously does not indicate that the established cult began during the Song, the Yuan or the Ming. It does, however, clearly demonstrate that the genealogy does not extend beyond these periods, and that the ritual efficacy of ancestors or of individuals whose religious function, 
usually marked by the seal of the master of martial arts and exorcism, was recognized. This efficacy was exactly the salient trait of the masters of exorcism, in contrast to Daoist priests (daoshi 道士), whose distinguishing feature was, among others, the practice of "lettered" (wen 文) rituals.

\subsubsection{Local Deities}

Before entering into a detailed discussion of strictly local deities, it seems opportune to include in this list divinities situated between the national cult and the local cult; what we might call "universal local deities" (see Table 5). The same holds true for the cult to the Supreme God of Camphor 樟樹太神, a tree cult, visible in all of China and generally linked to the cult of the God of the Soil, whose altar is placed at the foot of pluri-centenarian trees. The Zou 鄒 family of Xinhua district commissioned the statuette for the mother, née Wang 王, whose fate, revealed by a divinatory calculation of the date of her birth, was to be stricken by the nefarious spirits Kui 魁 and Gang 罡. The Zou family, with a son and a daughter, is associated in this cult with other donors, the Yangs 楊 and a Liang 梁, which makes this cult a communal cult, whose sworn witnesses (zhengmeng 証盟) were no less than the master of the place (dizhu 地主), Zeng Fawang 曾法網, and the master of the family (jiazhu 家主), Zou Fabiao 鄒法彪 (T0659).

Zhang Wulang 張五郎 is to an equal extent one of the well known deities, but one whose influence seems to be confined to the south of China. His cult is, in fact, attested to in the sect of Lüshan 閭山 in Fujian province. His place of birth is sometimes located in Jiangxi, sometimes in Guangxi, but he reigned uncontested in Hunan province. His surname is "the overturner of altars and the destroyer of temples" fantan pomiao 翻壇破廟 or the overturner of altars and grottoes fantan daotong 翻壇倒硐, not because he is known for his elimination of these sacred places, but because he is depicted upside down, his feet above and his head below. This unorthodox position came to him, according to one local legend, by way of a fight with a ferocious tiger that chased him off a cliff. Zhang's fall was stopped by a bush growing on the cliff side, but unfortunately he was head-first at the time; he died as a result. ${ }^{30}$ Another legend has it that this condition came about following his ritual competition with the Most High Old Lord (Taishang laojun 太上老君). Zhang Wulang went to study with the Old Lord, but the studies rapidly turned into a competition. The Old Lord threw him more and more difficult challenges, and he was only able to overcome them thanks to the aid of Jiji (急急, 吉 吉, or 姬姬), the daughter of the Old Lord, who had fallen in love with Zhang at first sight. The two lovers finally manage to escape, which provokes a murderous rage in the father, who throws "flying swords" (feijian 飛劍) to exterminate them. Once again, Jiji succeeds in deceiving her father by convincing him that they are dead. In order to be sure that the Old Lord can never find Zhang Wulang, Jiji fixes him in an upside-down position, so that he no

\footnotetext{
${ }^{30}$ See Guo, Zhongguo meishan wenhua, 32-39.
} 
longer has "either face or eyes." ${ }^{31}$ In the region of Meishan, Zhang is the God of Hunters: tiger hunters, hunters of small and big game, hunters with rifles, trappers. Hence one of the motivations for invoking Zhang Wulang is the following:

I will enter the mountain to hunt game, I will kill wild animals that I will bring to the altar, I will dismember them until death ensues. I implore you to protect me, disciple of the king of Meishan, that my body be more than thousands of fathoms high, that my fires illuminate the sky, that my current dog be transformed into 24 dogs entering the mountain such that . . Today, clasping my hands, I wish that the reverser of altars ancestor descend in person (onto the altar) (T0496).

Zhang Wulang has many identities, notably that of Zhang Zhao erlang 張趙二郎, but especially that of Zhang Shikui 張世魁. It was a certain Xie of the district of Ningxiang, initiated as a master of rituals and as a Buddhist, who addressed Zhang Shikui, the marshal of the army of furies (chang 猖), in order to obtain his help, so that “horses and chariots don’t stop, that to a thousand calls, there are a thousand responses; that to ten thousand calls, there are ten thousand miracles" (T0704). Zhang, chief of the Five Furies (Wuchang 五猖), is also the one who sacrifices a rooster to them; thus he is represented with a knife in his right hand and a rooster in his left (pl. 17).

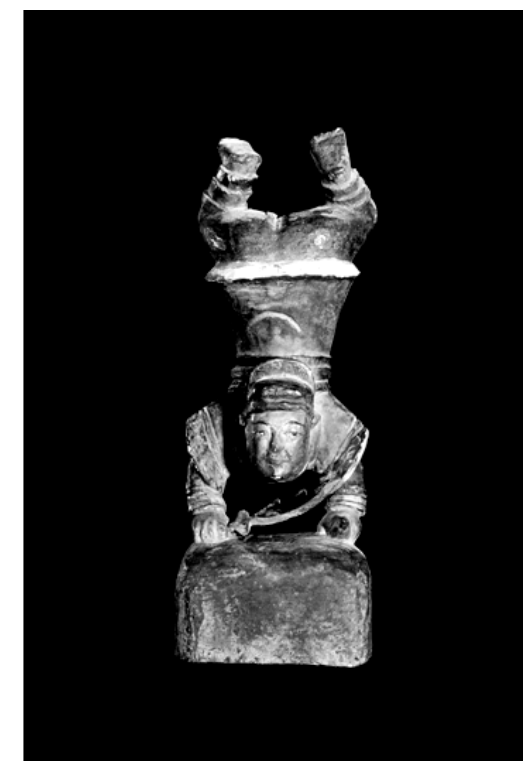

Pl. 17: Zhang Wulang, Ningxiang, 1947, h. $21 \mathrm{~cm}, \mathrm{~T} 0612$

Cliche Zhang Chaoyin OEFEO

\footnotetext{
${ }^{31}$ Idem.
} 
Table 5: The local deities in the PF and MH collections

\begin{tabular}{|c|c|c|c|}
\hline Name of the local divinities & Number & $\begin{array}{l}\text { Familial } \\
\text { consecration }\end{array}$ & $\begin{array}{c}\text { Communitarian } \\
\text { consecration }\end{array}$ \\
\hline $\begin{array}{l}\text { Zhang Wulang } \\
\text { 張五郎 } \\
\text { (張五郎 5) }\end{array}$ & \multirow{4}{*}{13} & 4 & \\
\hline 師祖翻壇到洞 張五郎 T0823 & & 1 & \\
\hline [番]張祖師 T0496 & & 1 & \\
\hline 番(翻)壇張世魁祖師 T0704 & & 1 & \\
\hline $\begin{array}{l}\text { Zhao jun Fazheng } \\
\text { 趙君法正 } \\
\text { (1686)原生于康熙丙寅年二月五日 } \\
\text { 卯時建生 T0256(2) }\end{array}$ & 13 & 8 & \\
\hline $\begin{array}{l}\text { Xiao jun Yilang } \\
\text { 肖君一郎 } \\
\text { 生於甲午年九月初九辰時 } \\
\text { [ ] 君一郎 } \\
\text { 生于甲辰年[...]九[月][...] } \\
0028 / C: 872\end{array}$ & 5 & 5 & \\
\hline $\begin{array}{l}\text { Wu jun Yongdao } \\
\text { 吳君永道 T0146-2-1 } \\
\text { 吳太公 T0146-2-2 } \\
\text { 本命生于乙巳年四月初六日酉時建 } \\
\text { 生 } \mathrm{T} 0354\end{array}$ & 3 & 3 & \\
\hline $\begin{array}{l}\text { Mao jun Shiqi'lang } \\
\text { 毛君十七郎 }\end{array}$ & 2 & 2 & \\
\hline $\begin{array}{l}\text { Wang jun Dou Sanlang } \\
\text { 王君斗三郎 T0090 } \\
\text { T0742-3-2 }\end{array}$ & 2 & 2 & \\
\hline $\begin{array}{l}\text { Wang jun Qilang } \\
\text { 王君七郎 }\end{array}$ & 2 & 2 & \\
\hline $\begin{array}{l}\text { Zeng jun Shisi'lang gong } \\
\text { 老祖十四郎公 T0126 } \\
\text { 四世祖曾君諱仲綸行十四郎公 } \\
\text { T0148 }\end{array}$ & 2 & 2 & \\
\hline
\end{tabular}


Journal of Chinese Religions

\begin{tabular}{|c|c|c|c|}
\hline $\begin{array}{l}\text { Cao jun Wan shiyilang } \\
\text { 曹君萬十一郎 T0817 } \\
\text { 曹君萬十一郎 } \\
\text { 生于本 [ ]王午年十一月二十五日午 } \\
\text { 時建 [生] T0169 }\end{array}$ & 2 & 2 & \\
\hline $\begin{array}{l}\text { Li Wan sanlang } \\
\text { 李萬三郎 }\end{array}$ & 2 & 2 & \\
\hline $\begin{array}{l}\text { Jiang jun Sanlang } \\
\text { 蔣君三郎 } \\
\text { 生于萬曆甲子年十一月十五日亥時 } \\
\text { 生 T0365 } \\
\text { T0389 }\end{array}$ & 2 & 2 & \\
\hline $\begin{array}{l}\text { Huang jun Jiuba'lang } \\
\text { 黃君九八郎 } \\
\text { 生于甲子七月十五日子時建生 } \\
\text { T0655 } \\
\text { 黄君九八郎 } \\
\text { 原命生於萬歴甲子年七月十五日子 } \\
\text { 時生子宫 T0749 }\end{array}$ & 2 & 2 & \\
\hline $\begin{array}{l}\text { Zou Faling gong } \\
\text { 邹法灵公 T0095-6-1 } \\
\text { 顕應 鄒公法靈 T0095-6-2 } \\
\text { (1576)原命生于萬歷四年丙子年十 } \\
\text { 月初五日辰岶(時)降生 T0095-6-1 } \\
\text { (1576)生于萬利(歷)丙子年十月初 } \\
\text { 五日辰時[生] T0095-6-2 } \\
\text { 㱀法靈公 T0291 } \\
\text { (1576)生於明萬歷丙子年十月初五 } \\
\text { 日辰時生 }\end{array}$ & 2 & 2 & \\
\hline $\begin{array}{l}\text { Luo jun Sanlang } \\
\text { 罗君三郎 }\end{array}$ & 2 & 2 & \\
\hline $\begin{array}{l}\text { Zhangshu taishen } \\
\text { 樟樹太神 T0659 }\end{array}$ & 1 & & 1 \\
\hline $\begin{array}{l}\text { Xiao jun Sanlang } \\
\text { 蕭君三郎 0405/C:1615 }\end{array}$ & 1 & 1 & \\
\hline $\begin{array}{l}\text { Xu jun Sanlang (dizhu) } \\
\text { 地主許君三郎 T0008 }\end{array}$ & 1 & 1 & \\
\hline
\end{tabular}




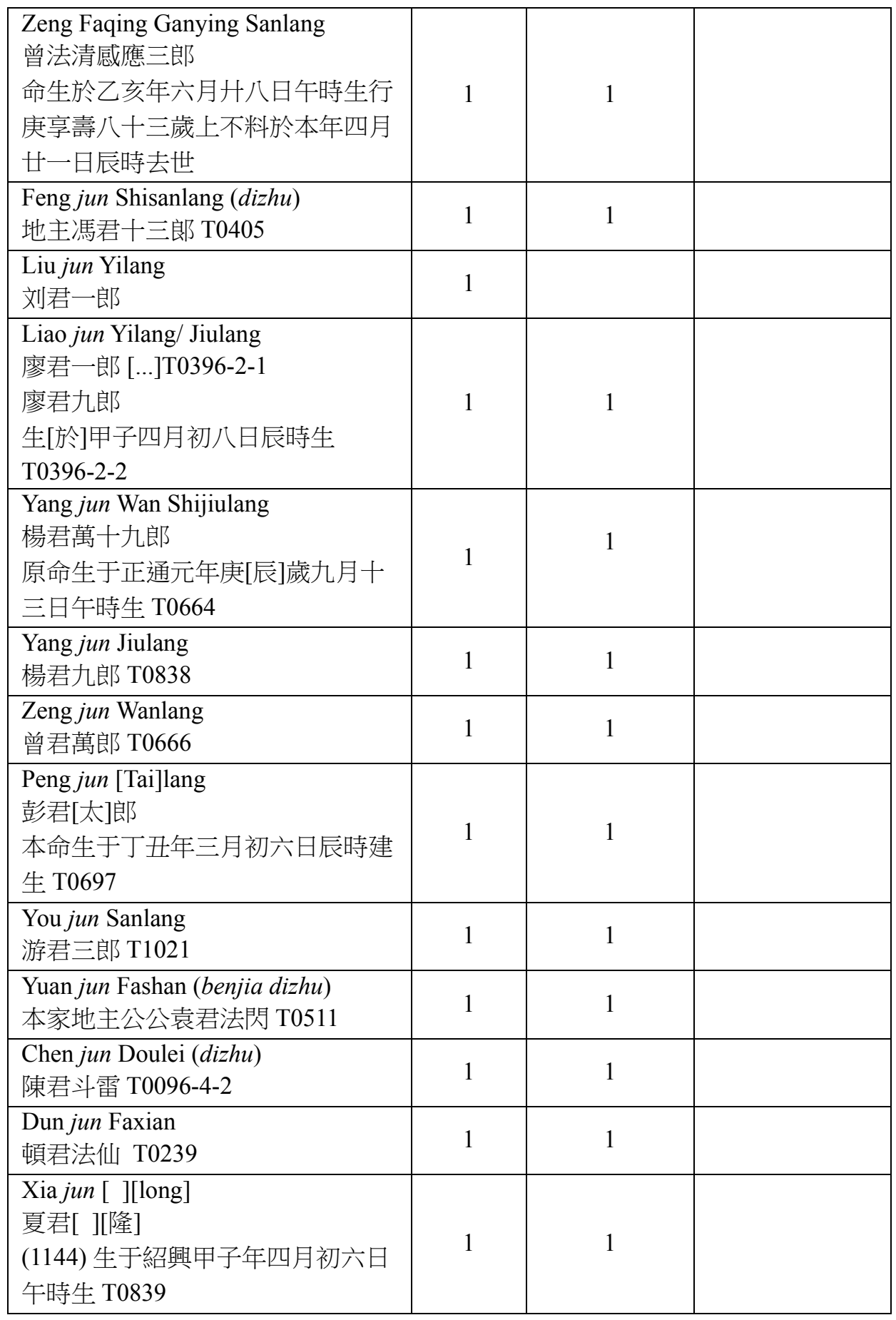




\begin{tabular}{|l|c|l|l|}
\hline $\begin{array}{l}\text { Yan jun Fakui } \\
\text { 鄢君法魁 T0763-2-1 } \\
\text { 法師 征君法魁 T0763-2-2 }\end{array}$ & 1 & & 1 \\
\hline $\begin{array}{l}\text { Xiao jun Erlang } \\
\text { 当君二郎 0308/C:1476 }\end{array}$ & 1 & & \\
\hline $\begin{array}{l}\text { Wan jun Jiulang } \\
\text { 晚君九郎 0309/C:1418 }\end{array}$ & 1 & & \\
\hline $\begin{array}{l}\text { Feng jun Sanlang } \\
\text { 奉君三郎 0445/C:805 }\end{array}$ & 1 & & \\
\hline $\begin{array}{l}\text { Deng jun Qilang } \\
\text { 鄧君七郎 } \\
\text { 生於癸丑[岁]十月十三戌時 } \\
\text { 0020/C: } 1522\end{array}$ & 1 & & \\
\hline TOTAL & $\mathbf{7 9}$ & $\mathbf{7 3}$ & $\mathbf{2}$ \\
\hline
\end{tabular}

Besides the divinities situated between the two categories or "national" and "local", we have selected the statuettes whose names include the word "lang" 郎. Many interpretations have been given to this term: some remind that it was a "title" employed, beginning in the Song dynasty, for the sons of the family, with the addition of the ordinal number $1,2,3, \ldots$ following the order of birth. In the same vein, these are the disciples of the same master, to whom lang is attributed preceding an ordinal number corresponding to "first disciple", "second disciple", etc. In the central region of Hunan, the local specialists relate this designation to the degree of a master of exorcism, who, as a function of his years of training, includes at the beginning of his career the word $f a$ 法 in his initiation name (three years), then, as the years go by, that of jun 君 (six years) and finally that of lang (nine years), which designates a master at the peak of his career. Others claim that lang is obtained after three generations in a shigong family. In any case it is certain that among the Yao and the She 畣, all males are initiated and receive an ordination name containing the character $f a$ 法 and that those whose names begin with the character lang were necessarily initiated. We find the same procedure of langming 郎名, faming 法名 and duming 度名 in the Hakka genealogies, which supposes an initiation ritual called fengchao 奉朝, conducted for the groom before his wedding. This practice, which is also a process of ancestralisation (since the initiate thus enters the family's genealogy) has disappeared, at least among the Hakka, by the 18th century. ${ }^{32}$

Let us remember first and foremost that we are in a religious context, in the frame of a cult devoted to a divinized person; a situation, after all, entirely different than a strictly familial setting. It is not irrelevant that the "langs" are in most cases the object of worship

${ }^{32}$ See Chan Winghoi, "Ordination Names in Hakka Genealogies: A Religious Practice and Its Decline," 65-82. According to the author, it was the wave of genealogy-writing which led families to adopt more "literary" names. 
outside of what, strictly speaking, constitutes the family, even if the cult most often remains limited to a village, or possibly a district. Frequently paired with lang, designations such as shizu 師祖 (lineage master), or dizhu 地主, master of the place, necessarily designate the individuals whose sphere of influence far exceeds the direct line of the family. In the ritual books of the region, the ancestral masters of the line particular to a master of rituals are generally invoked after the enumeration of the great divinities of the national pantheon, and followed by the list of the founding masters of the line (benshi 本師), finally arriving at the direct masters of the officiant. The expression "master of the place," in contrast to "master of the family" (jiazu 家主), even if the two types are sometimes confused (the jiazhu of a family can become a dizhu for the other families, or a heteronymous allied family can have as jiazhu that of the prominent local family), refers to the explanation that is provided by the religious specialist to the individuals who, in distant times, were known for their religious merit. That merit was based on the efficacy of their rituals (fali 法力), their exceptional capacity to resolve - with divinities as intermediaries and in a ritual manner-bad weather, droughts, invasions of insects and of brigands. In short, they were known for their charisma and not simply for being the founders of a clan. The same holds true for the masters of the family who are known within a family for playing a particular role, and not simply for being the first to have established the family in Hunan (shizu 始祖). Outside of the article or designation attached to the family name, the particular status of these local divinities resides in their long life. They tend to be venerated three, four centuries or more after their birth, a phenomenon that reveals their extraordinary stature and saintliness.

Of Xiao jun Yilang 肖君一郎 we have five statuettes coming from Anhua, Xinhua (2), Shaoyang and Xinning, thus covering a vast territory from the northern to the southern parts of Hunan province (pl. 18). It is, however, not certain if it is the same person in each case, but the cult that is dedicated to him is always carried out by devotees whose family name differs from his. The first consecration took place in 1872, the others at the beginning of the 20th century. The five members of the Zuo 左 family, of whom the first two are either brothers or first cousins, performed this consecration for a specific occasion: the statue was made for the birth of three sons in Xinhua district — which brings the number of statuettes to three just for Xinhua. During a move to Xinning, it was soiled by a stove moved by a woman and the divinity demanded that the Zuos remake it, and a sum of 3,200 cash (wen 文) was allocated to this end (T0545). 


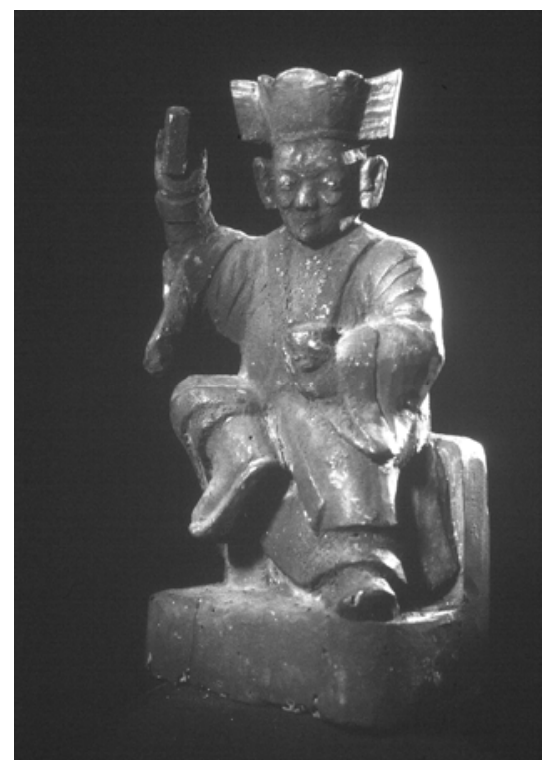

Pl. 18: Xiao jun Yilang, Shaoyang, 1872, h. 24 cm, T0087

Cliche Claude Delhaye OEFEO

Wang jun Qilang 王君七郎 and Zeng jun Shisi'lang 曾君十四郎 and Feng jun Sanlang 奉君三郎 are mentioned in the liturgical calendar of Qin Guorong 秦國榮, a Daoist priest (daoshi 道士) also ordained as a master of exorcism (fashi 法師), who resides in Xinhua. A Chen 陳 of Anhua (T0072) and a Zou family of Xinhua (T0415) pay homage to Wang-theseventh, the first in 1872 , the second at an undetermined date.

In the 1910s, the lord Zeng receives a cult in the same village from two of his distant descendants, a cult not conducted by a man of the Zeng family, but by a mother née Zou 鄒, and another née Zhou 周, both married to a Zeng and accompanied by their sons and daughters-in-law. The woman Zou addressed herself to a grand ancestor, a famous "Confucian" ( $r u$ 儒) of the Song, who was said to have cleared the mountain, "made the foxes flee", and learned his art ( $f a$ 法) to the equal of the immortals in the Fuzhou 撫州 prefecture of Jiangxi (T0126). In regard to the woman Zhou, who, among other things, expressed wishes for her health and longevity, she alludes to an ancestor of the fourth generation, of the given name Zhonglun 仲綸, who transmitted the Yuanhuang 元皇 teachings within the family, and the true teaching of the Dao and the De of the Old Lord (Laojun 老君). Due to this transmission everyone in the three cantons (xiang 鄉) in the district of Xinhua honored him, and the clan was able to profit from his good deeds (T0148).

The lords Xu 許, Feng 馮, Chen 陳 and Yuan 袁 are referred to as being masters of the place (dizhu). Feng-the-thirteenth was consecrated in 1867 by Wu Biyang 伍草楊, with his wife, née Liu 劉, his son Fawei 發位, his daughter-in-law née Chen, his grandsons and his 
granddaughter (T0405). Even though the location is incomplete, one can suspect, in regards to the statue of Xu jun Sanlang 許君三郎, which was consecrated in 1879 by a woman Liu 劉 married to a Wu 伍 and her grandsons Fada [發]達, Fayuan [發]遠 and Fahuang [發]煌 (T0008), that those who consecrated it, while not exactly belonging to the same family, do belong to a branch of first cousins of the Wu. The first consecration of Chen jun Doulei 陳君 斗雷 dates back to 1743 and the second to 1924 (T0096). Undoubtedly, these are descendants of the Guo 郭 family who, two centuries earlier and in the identical location, paid homage to lord Chen. Yuan jun Fashan 袁君法閃 is the master of the place of the family 本家地主, a complicated way of saying that the local divinity Fashan is to an equal extent the ancestor of Yuan Keyou 袁[克]友 who, in 1926, dedicated this statue to him (T0511).

The last two examples show without a doubt that the designation lang is not a condition sine qua non for designating local divinities. Zhao Fazheng 趙法正, born in 1686, is from this point of view remarkable. He alone is represented by a dozen statues that come from Anhua district, but from different villages and families, and nearly all of which date from the Republican period. ${ }^{33}$

Perhaps we would have omitted Dun jun Faxian 頓君法仙 (Pl. 19) from our list if the manuscript of "the opening of eyes" (consecration ritual of a statuette) of a sculptor of the district of Xinhua, Feng Xiaoyuan 奉孝元, did not carry his name inscribed among his ancestral masters, who are organized in two distinct lists. The first list carries the sixteen names of the founders of the lineage of the province of Jiangxi, who must in fact correspond to 13 generations (three have Ting 廷 for their generational character, and the other the character Yong 永); the second, that which must designate the benshi 本師, entitled "the founders of the Yuanhuang sect" 元皇啟教, ${ }^{34}$ starts with Dun Faxian and includes 12 names total. The statue of Dun was consecrated in 1798 (T0329). Lord Dun, then, must have been born at least around 1700 and probably well before, around the 16th century, if one supposes that a generation corresponds on average to 30 years, the thirteenth generation $(13 \times 30=390$ years), that of Feng Xiaoyuan, is located around the second half of the 20th century $(x+390=$ $1950, \mathrm{x}=1560)$.

\footnotetext{
${ }^{33}$ See Michela Bussotti, "Hunan zhongbu diqu "Jiating diaoxiang"de lüeshu."

${ }^{34}$ Yuanhuang 元皇 is the name of a sect, or an order, that according to the local religious specialists refers to the shigong (or fashi), master of exorcism, versus Former Heaven (Xiantian) order which designates the taoist priests (daoshi). The term yuanhuang appears very frequently in the collections and concerns Anhua, Xinhua, Ningxiang and Yiyang districts. The first occurrences date from 1794 and 1798. The name of Yuanhuang is always associated with the use of talismans, and esoteric invocations (zhou 咒) and formulas (jue 诀), for expelling demons, and pestilence, in order to return to a peaceful situation. See Alain Arrault, "Religious Practice in China". Some local sources indicate that Yuanhuang is a contraction of the name given to Laozi during the Tang dynasty: Xuanyuan huangdi 玄元皇帝, see Li Xinwu, "Lengshui jiang Yang Yuanzhang tan shigong yu daoshi de yitong bijiao," 273.
} 


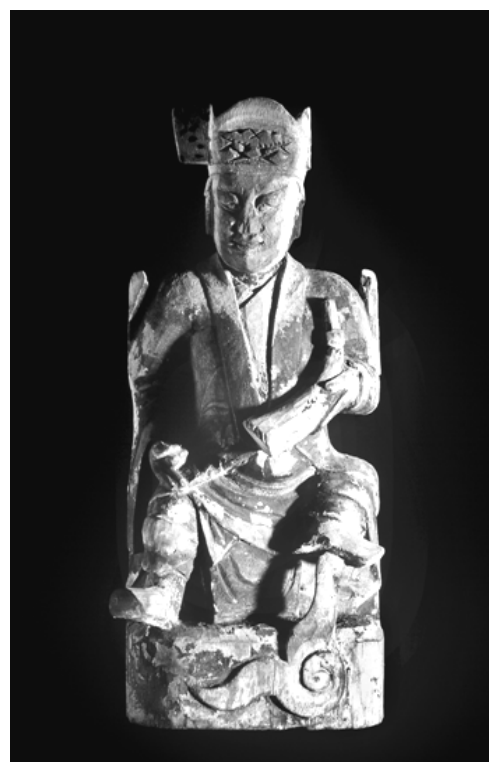

P1. 19 : Dun jun Faxian, Xinhua, 1798, h. 22.6 cm, T0239 Cliche Zhang Chaoyin CEFEO

We have already met $\mathrm{Wu}$ Yongdao, born in 1485, who was known for his martial exploits. In the canton of Chang'an 常安, in Anhua, Kang Lisi 康立思 and his family consecrated a statuette to $\mathrm{Wu}$, whom they refer to as yuhua zhushi 羽化祖師, the spiritual master "transformed into a feathered being". The consecration was accompanied by an explicit request for the wife of the second son, who has health problems (T0354). In 1947, it's the turn of Yu Lijun 喻理均 of the Changfeng 常豐 canton of Anhua to be a devotee of Wu Yongdao (T0298). Zou Faling 㮲法靈 is also one of our acquaintances. Born at the end of the Ming, one of his two statuettes contains several certificates and talismanic writings, two of which might lead one to believe that we are in the presence of a first consecration followed by a second, a practice consisting of re-consecrating the same statuette and of keeping the preceding certificate with the new one, a phenomenon that we find in other statues. We're evidently dealing with the same family, the Luos 羅 of Xinhua who, one knows not why, have chosen to mention the expenses pertaining to a statuette whose dimensions, it is true, are larger than the average $(40 \mathrm{~cm})$. The devotees have spent a little less than 300 cash (wen) on an indeterminate date. They did this because the principal contributors Luo Mingshi 羅明实 and Luo Shiyu 羅世育 were stricken by the nefarious spirits Kui and Gang. The second document, with Luo Fuwen 羅傳文 at its head, lists all the contributors and their financial contributions, the total of which amounted to a little less than 5,000 cash, this time for the protection in particular of the medium (jiaoma 腳馬) Luo Shilin 羅世林 who, curiously, carries the same generational character as Luo Shiyu (are we really in the presence of two consecrations, or of two consecrations whose dates were close to one another?). The only date 
that we have is that of 1879 , placed before a group of talismans (T0095). As we have seen, between 1903 and 1906 the statuette of Xiao jun Yilang had cost the Zuos 3,200 cash, the cost of which probably included the fee of the sculptor, but also that of the consecration ritual. The second statuette of Zou was commissioned by a woman, née Peng 彭, married to a Luo, and residing in the district of Shaoyang, located to the south of that of Xinhua. Madam Peng, who presented herself as a disciple whose destiny was determined by the sixth star of the Northern Bushel, is, like Luo Mingshi and Luo Shiyu, under the nefarious influence of Kui and Gang (T0291).

\subsubsection{Ancestors}

That one makes statuettes for national divinities is a common phenomenon in all China and elsewhere. It is, however, less common to run into locally anchored divinities whose cult sometimes does not go beyond the boundaries of neighboring villages. But one characteristic of the Hunan statuettes is in how they represent ancestors, distant or close, in sculpture. ${ }^{35} \mathrm{We}$ know that this practice seems to have appeared at least from the Song, with the statues of the imperial family, in spite of the constant calls to orthodoxy by the Confucian literati, who recommended using funeral tablets and not images for the cult of ancestors. ${ }^{36}$ The prescription against images was visibly loosened during the Qing dynasty, since this period saw the appearance of painted portraits of direct ancestors, the origin of the current custom of placing a photo of the deceased on the altar. But to this day, outside of Hunan, it is very rare to find evidence of statuary dedicated to members of the family.

Table 6: Types of designation for the statuettes dedicated to members of the family

\begin{tabular}{|c|c|c|c|}
\hline Designation & & Number & \\
\hline Shizu 始祖 & First ancestor & 1 & \multirow{6}{*}{12} \\
\hline Taizu 太祖 & Grand ancestor & 6 & \\
\hline Taigong 太公 & Grand ancestor & 2 & \\
\hline Gu xianzu 故顯祖 & Ancestor & 1 & \\
\hline Guzu 故祖 & Ancestor & 1 & \\
\hline Lao waizu 老外祖 & $\begin{array}{l}\text { Ancestor on the } \\
\text { maternal side }\end{array}$ & 1 & \\
\hline Zubi 祖妣 & $\begin{array}{l}\text { Great paternal } \\
\text { grandmother }\end{array}$ & 2 & 2 \\
\hline Zukao 祖考 & Grandfather & 3 & 7 \\
\hline
\end{tabular}

${ }^{35}$ Keith Stevens was the first to point out this type of statuary, see K. Stevens, "Portraits and Ancestral Images on Chinese Altars."

${ }^{36}$ See on this subject, P. Ebrey, "Portrait Sculptures in Imperial Ancestral Rites in Song China", and "The Incorporation of Portraits into Chinese Ancestral Rites." 
Journal of Chinese Religions

\begin{tabular}{|c|c|c|c|}
\hline Zufu 祖父 & Grandfather & 2 & \\
\hline Dengcao zufu 登曹祖父 & Grandfather & 1 & \\
\hline Lao zugong 老祖公 & Paternal grandfather & 1 & \\
\hline Zumu 祖母 & Grandmother & 1 & 1 \\
\hline Tang bozu 堂伯祖 & Paternal grand uncle & 1 & \multirow{3}{*}{3} \\
\hline Gupo 姑婆 & Paternal grand aunt & 1 & \\
\hline Jiatang gupo 家堂姑婆 & Paternal grand aunt & 1 & \\
\hline Fuqin 父親 & Father & 21 & \multirow{10}{*}{53} \\
\hline Xiankao 先考 & Father & 15 & \\
\hline Xiankao 顯考 & Father & 5 & \\
\hline $\mathrm{Fu}$ 父 & Father & 4 & \\
\hline Gu xiankao 故先考 & Father & 3 & \\
\hline Xianfu 先父 & Father & 1 & \\
\hline Qinggu xiankao 清故先考 & Father & 1 & \\
\hline Fuqin fushui 父親符水 & Father & 1 & \\
\hline Fuqin lingshen 父親靈神 & Father & 1 & \\
\hline $\begin{array}{l}\text { Xianshi xiankao fuqin 仙逝 } \\
\text { 顕考[父]親 }\end{array}$ & Father & 1 & \\
\hline Mu 母 & Mother & 4 & \multirow{7}{*}{12} \\
\hline Muqin 母親 & Mother & 3 & \\
\hline Xianbi muqin 先妣母親 & Mother & 1 & \\
\hline Tangmu 堂母 & Mother & 1 & \\
\hline Laomu 老母 & Mother & 1 & \\
\hline Gumu 故母 & Mother & 1 & \\
\hline Cimu 慈母 & Mother & 1 & \\
\hline Bofu 伯父 & Paternal uncle & 5 & \multirow{4}{*}{9} \\
\hline Shuzu 叔祖 & Paternal uncle & 1 & \\
\hline Shufu 叔父 & Paternal uncle & 2 & \\
\hline Shu waizu 叔外祖 & Maternal uncle? & 1 & \\
\hline Bomu 伯母 & $\begin{array}{l}\text { Aunt (wife of the } \\
\text { father's eldest }\end{array}$ & 1 & 1 \\
\hline
\end{tabular}




\begin{tabular}{|c|c|c|c|}
\hline & brother) & & \\
\hline Yuefu 岳父 & Father-in-law & 2 & \multirow{2}{*}{3} \\
\hline Yuemu 岳母 & Mother-in-law & 1 & \\
\hline Baoxiong 胞兄 & Eldest brother & 1 & \multirow{2}{*}{2} \\
\hline Guxiong 故兄 & Eldest brother & 1 & \\
\hline
\end{tabular}

From the first or the great ancestor down to the eldest brother, everyone is entitled to a statuette (see Table 6). Effigies of fathers are most common, followed by those of the mothers and the important forefathers. The uncles outnumber the grandparents, the grand uncles and grand aunts. If, conforming to the clannish organization that requires the paternal branch to dominate over the maternal line, the male parents occupy a choice place, the maternal lines are nonetheless not inexistent, starting of course with the mothers, then by the distant ancestors on the maternal side, the maternal uncles, the aunts and the parents-in-law. Some have put forward the survival of a form of matriarchy or of the matriarchal practices of the Yao and Miao ethnicities who occupied the province for many centuries as a reason for this, but this would be to forget that the women thus venerated are not always a simple name inscribed in a genealogy, but that they were among the religious specialists. The miaoxian 妙 仙 and the xianniang 仙娘, all represented with a bowl of lustrous water and a command staff, or making the magical gesture of the sword, are not tranquil women, but are invested with special religious powers (Pl. 20). Perhaps they were mediums, exorcists, healers, midwives or revealed as such by miracles that they pulled off over the centuries through mediumistic communication. Among them, we have the ancestors: The Immortal Lady, née Deng 鄧, of the given name Jiaxue 嘉學 and of the public given name Wenyu 文玉, is an ancestor (xianzu 先 祖) to whom the paternal grandmother (gong popo 公婆婆?) established a cult. The consecration certificate says that no one knows when Lady Deng lived, nor where she obtained the Dao. Nothing precise is known about her, with the exception of the fact that it was necessary to make offerings to her on the ninth day of the first month of the year. Even though an old statuette still existed, nobody dared open it to find out more. No matter the details, what is important is that Lady Deng protected the family and for that reason received, just like the mother and the father, incense offerings (shou xiangyan 受香烟). As a result, Xie Yongling 謝永錂, with wife, sons, daughter, daughters-in-law, grandsons, had this statuette installed on the familial altar on the eighth day of the first month of the seventeenth year of Qianlong, in 1751 (T1027). Lady Zeng 曾, a great grandmother born in 1741, is also a miaoxian, as well as the mother of Dai Yuzhen 戴裕禎, born in 1858 and consecrated in 1920 (T0270). Liu Daoli 劉道立, in contrast, chose his mother-in-law to consecrate. She was born in 1827 and died in 1880, and is of the xianniang status (T0535). 


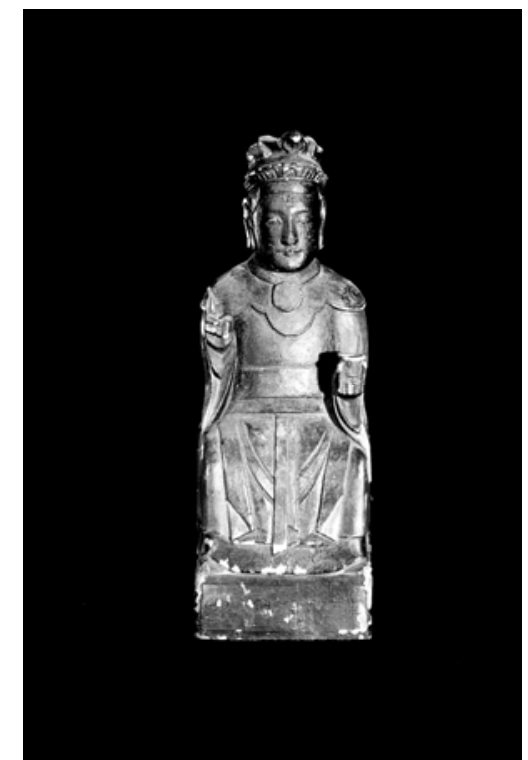

Pl. 20 : Xiong shi xianniang, Anhua, h. $27.8 \mathrm{~cm}$, T0693

Cliche Zhang Chaoyin CEFEO

Deng Yongmian 鄧永綿 dedicated a statuette to his father, Deng Daixian 鄧代賢, in 1901. Born in 1848, Daixian, of the public given name Rongchang 榮昌, surname Baishi 百 世 and of the registration name (luming 籙名) Yuanxing 遠興, received a function (zhi 職) and a charge (ren 任) from his master Zhou Jixiang 周吉祥, representative of the sixtyfirst generation of Celestial Masters, in 1863. Those responsibilities were augmented in 1895 thanks to a second master, Zhou Yihe 周一和 (T0671). These biographical indications show that we are indeed in the presence of a Daoist priest, a rare occurrence with the statuettes, which generally represent exorcist masters. But we do not know whether the son paid homage to the father or the priest, whose disciple he would have been. If, in this case, nothing allows us to conclude that a master/disciple relationship existed between father and son, there are, however, numerous examples where this relationship is unambiguous.

Xiong Daotong 熊道通 is both father and initiation master (fuqin dushi 父親度師) to his son Xiong Shikuan 熊仕寬, upon whom befell the ordination name (faming), Chuandu 傳度 (T0537 ); the same goes for Peng Weiqing 彭魏卿 towards his son, born in 1894, who had studied the Orthodox Teachings of Elder Ge (Ge Weng zhengjiao 葛翁正教) with him (T0584). The expression fushi 父師, father-master, seems to be more ambiguous. Out of fifteen occurrences, seven contributors presented themselves as sons, eight as devotees and disciples, but with an identical family name. The ambiguity was possibly maintained intentionally, as it is true that the disciple, once he is admitted, must behave towards his master as a son towards his father- the rite of admission of the disciple is in fact very close to that of adoption. Zou Hegui 邹和珪, born in 1805 and deceased in 1881, has for his 
ordination name Fuzhang 福璋 and for his “sorcerer” name (wuming 巫名) Fazhang 法璋. His son, Zou Benheng 邹本恒, received as an initiation name Fayun 法雲 and one part of his vows concern his status as master of rituals: "I implore your protection so that in the ten regions I can carry the incense and the fire, that my religion and my altar of thunder be at its zenith, that my body carry the horses and the soldiers of the five garrisons to aid my country and save my people...” (T0615). Wu Douyu 伍都郁 also calls Zou Hegui father-master, even though he is visibly not of the Zou family, but he received an ordination name Benli 本立, whose character ben 本 is identical to that of Zou Benheng and his wife is Zou, two good reasons a priori for him to consider himself a son (T0714). The two statuettes of Zou Hegui were consecrated on the same date (1882) with identical votive formulas. An uncle and a eldest brother can also be initiators; they are then called shufu dushi 叔父度師, uncle and master of initiation, and duxiong 度兄, brother-initiator. Consider, for example, Zeng Fayi 曾 法詒, who ordained (jiedu 界度) his younger brother at the moment of “climbing to the celestial department" (deng cao 登曹), which designates the younger brother as "universal legatee", the one to whom a master leaves his ritual books and reveals his last secrets at the moment of his death, together with the consent of the divinities that one obtains through the casting of divinatory blocks (T0162).

\subsubsection{The Masters}

It is, of course, the spiritual masters that one must venerate first and foremost. These are, as we have seen, the national and local divinities, like Yaowang, Lu Ban, Zhang Wulang and Lutou, who are the zushi 祖師 of a religious order or of a guild. Other less well-known figures have also received this title.

In 1896 Chen Faming dedicated a statuette to the zushi Zhang jun Fayu 張君法玉, so that the furies, palanquins, and horses set off together, "so that the Ten Chiefs of the Furies, the horses and the soldiers of the Five Furies (wuchang 五猖) receive sacrifices and recompense on the altar of thunder, ... that on top [during the day] the soldiers do not stop, that during the night the horses do not rest; that the Dao of the family be at its apex, that there be great celebrations, that the incense and the fire of the thunder altar be protected, that the founder and ancestor reveal his ritual [power] and his dragon body (chufa longshen 出法龍身), that from generation to generation incense and fire manifest their miraculous power, that the great ritual methods of Jiang Fazheng 姜法正 communicate with the divinities, that one orders the horses, the soldiers and the furies to go to the grottos and the temples, that the general Liu 柳 將軍 come, that by his mouth the ritual power (fali 法力) communicate with the divinities...” (T0624).

Peng Tingwu 彭庭武, surnamed Xiqi 西溪 with the initiation name Fawu 法武, was born in 1531. He was initiated in the service of the imperial house, but in order to get to know the authentic rites, he went to Wuzhou 武洲, present day Changde 常德 in Hunan, to learn the art 
of exorcism. ${ }^{37} \mathrm{He}$ conducted the religious services with great respect, and following the ritual rules he commanded the divinities. Under the Wanli era (1573-1619), a celestial scripture (tiansh $u$ 天書) ordered him to ascend to the Celestial Palace. Mounted on a white horse, he arrived at the Celestial Palace and the Jade Emperor offered him pure water. Be it to obtain good weather or rain, do away with calamities, expel demons, protect the men and women, exorcise the difficult states of the children, decide between life and death, one needs only to ask for him to respond. Altars have been installed to him everywhere, he appears everywhere; neither immortal nor saint, he descends in person and reveals his efficaciousness, he the spiritual master (zushi) and authentic lord (zhenjun 真君) (T0390)!

Although the expression employed in these last two cases and in many others is that which characterizes the spiritual masters, it must be a corruption of the language, by confusion or by the desire to aggrandize these masters, that one has replaced shizu 師祖 with $z u s h i$ 祖師, the "ancestral masters" with the "spiritual masters." It is true, however, that it is sometimes difficult to distinguish between the two, but the ritual books are in general clear enough to distinguish the list of spiritual masters, from the greater to the less significant, from the list starting with the founder of the lineage, followed by his direct heirs, and finally ending with the direct masters. Dun jun Faxian, whom we have already met, was without doubt one of the ancestral masters of the statuette sculptors. In another realm, but in a similar context, Lu Yinyou 蘆蔭佑, initiated under the name Fayou 法有, seems to have been born under stars unlucky for his parents. For this reason he "entered into religion" and took an initiation master of the Altar of Thunder named Tang Faying 唐法應 with whom in 1880 he studied the Orthodox Teachings of Guinan ([Gui]nan zhengjiao 桂南正教, and the orthodox teachings of Huainan 淮南?). But it is not to the latter that Lu consecrated a statuette, but to the ancestral master (shizu) Zhao jun Faquan 趙君法全, a filial gesture that a good disciple should make (T0555). ${ }^{38}$ Eleven statuettes carry this title in their name, one of which is that of Zhang Wulang, who became, as it happens, ancestral master rather than spiritual master.

The direct masters are legion. Besides the family masters that we have previously evoked, these masters are designated by many titles. It can be the very modern term of shifu, with the second character sometimes written as $f u$ 父 (father), sometimes $f u$ 付 (sic!) or $f u$ 傅, the last one being the proper one. In only three examples that we have, it is indeed disciples (dizi 弟子 or tudi 徒弟), with different family names from their master, who proceeded to the "opening of the eyes" of a statuette in the second half of the 19th century (T0761: 1844, T0216: 1855)

\footnotetext{
${ }^{37}$ Later in the certicate, it is the Emperor of the Origin (Yuanhuang) who ordered him to study the art of exorcism of Wuzhou 武州.

${ }^{38}$ Another Zhao jun Faquan, of the personal given name Guicheng 貴成, and of the public given name Hanzun 漢尊, born in 1695 in the district of Shaoyang and dead in 1761 in the district of Ningxiang, is venerated by a certain Deng 鄧, master of exorcism of his state, living in the same district as Lu, Yiyang 益陽, but in a neighboring canton (T0208). In view of the date of Lu Yinyou's “entry into religion" (1880), the consecration date of 1908 for this second lord Zhao could have coincided with that of the statuette commissioned by Lu Yinyou. Deng calls Zhao jun spiritual master, zushi.
} 
and at the beginning of the 20th (T0793: 1919).

The shigong 師公, who must be distinguished from the gongshi 公師, are part of the lot. Out of fourteen occurrences, ten concern disciples whose family name differs from that of their shigong. Xue Faqi 薛法棋 and Xue Fazhen 薛法珍, who pay homage to Xue Fazhao 薛 法照, are the exception to the rule, even though nothing prevents these Xue from not being descendants in a direct line. The two Xues, disciples who practice the art of "sorcery" (xingwu dizi 行巫弟子), studied the method of Meishan talismans of the order of Yuanhuang (Yuanhuang Meishan fufa 元皇梅山符法). In the certificate of consecration, they give in sixteen quatrasyllabic phrases a striking description of the statuette and of their master:

The statue of the effigy of our master is an imitation of his goodness.

It preserves his ritual (force); in it lies his authority.

Parting on a horse, it flies like lightning.

By horse it returns to the altar, which [the soul of our master] inhabits (shi ping shi yi 式憑式依). ${ }^{39}$

It eliminates the spirits possessing people, it delivers them from misfortune.

We reward it with alcohol, we burn incense to it;

When we think of the marvelous efficiency of our master, he descends immediately to our sides;

As to his merits which we invoke, we will always hold them in our hearts and we will never forget them (T0400).

The shigong Gong Liyuan 竟禮元, who was born in 1851 and died in 1896, is called upon in 1937 in two quite ordinary vows, but by a disciple in charge of an altar (xingtan dizi 行壇弟子), Luo Douxian 羅都先 (T1024). Wang Chengfu 王成馥, with the public name Guiquan 桂泉 and the ordination name Fagui 法桂 has, according to him, taken as an initiation master Yu Fayun 喻法雲 in 1891 (?), the same year he made a statue to him. Wang also mentions his three shigongs: Liao Faguang 廖法廣, Wu Fayu 吳法餘 and Wu Faxiang 吳 法祥. With his four masters, Wang studied "at their knees" all sorts of secret formulas and talismans to assemble the furies of Meishan of the Yuanhuang order (Yuanhuang Meishan shou chang zhuban fufa 元皇梅山收猖諸般符法) (T0590). Lu Guoli 盧國禮 commissioned a statue, but three individuals are mentioned: his master of initiation, Lu Fazhen 盧法珍, his shigong Zhou Farong 周法榮, and his shitai 師太 Zhou Fasheng 周法勝. ${ }^{40}$ This triad of masters, an imitation of the three masters of Daoism (jing 經, $j i$ 籍, $d u$ 度), is iconographically represented by three statuettes fixed on the same pedestal, a unique assembly in the collection

${ }^{39}$ A similar expression, lingshuang shiping 靈爽式憑, is employed in relation to the statuette-object to signify that the soul of the deceased remains there (T0834, T0578). For a statuette of Lu Ban, "by leaning against it, [Lu Ban] descends down here” 式憑式降, see T0780.

${ }^{40}$ Concerning the expressions shigong and shitai, see above p. 20. 
which was commissioned by a certain Li for his father-master (fushi), born in 1807, his gongshi (same family name), born in 1786, and his initiation master (dushi 度師), Liu Fayun 劉法雲, born in 1823 (T0678).

The initiation masters (dushi) — or the "initiation masters who taught in person" (qinkou $d u s h i$ 親口度師)—form by themselves a category of statuettes, with a total of more than sixty pieces, a distinctly larger number than the other types of effigies of direct masters. Among them, forty-four concern extralineal relations. One studies with these masters the Orthodox Religion of the Emperor of the Origin (Yuanhuang zhengjiao 元皇正教) (T0106, T0482, T0767, T0327), which is presented with several variants: sometimes it is the apprenticeship of all the talismanic methods of Yuanhuang of Huainan 淮南 (T0303), sometimes of the secret incantations and talismans of Xueshan 雪山 of the order of Yuanhuang of Huainan 淮南 (T0303), or even the ritual incantations of Yuanhuang for "raising and lowering (pengtui 捧 退)” (T0569). ${ }^{41}$ The disciple Yang Guangjin 楊光錦, surname Zhuhuang 竹簧, initiation name Fashi 法食, enters the School of Rituals of Shaoxing of the Thunder Altar of Lingyuan (Lingyuan leitan Shaoxing fayuan 靈元雷壇邵興法院) in 1925 to study the incantations and the talismanic writings of the Ladies of Meishan (Meishan niangniang 梅山娘娘), of Xueshan 雪山, and of the five thunders of Xiantian yuanhuang 先天元皇 (the Emperor of the Origin of Former Heaven) (T0045). It is with Kang Miaoling 康玅零 (Pl. 21), born in 1783, that Yang Shaorong 陽紹容 too has learned the usage of talismans and incantations of the Orthodox Religion of Former Heaven of Yuanhuang (Yuanhuang daofa xiantian zhengjiao 元皇道法先 天正教), of arts that allow one to heal diseases, eradicate malevolent powers, appease and expulse pestilent spirits, and "sweep away" pollution (T0258). But the education is sometimes much broader or more specialized. A disciple has thus acquired the principles of the Orthodox Religion of Buddhism and of Sorcery (Wushi zhengjiao 巫釋正教), for this receiving an ordination name including $f a$ and a Buddhist name (T0466). Others are even more eclectic, embracing the Orthodox Religion of the Emperor of the Origin, or the Daoism and Buddhism of Former Heaven (Xiantian fodao yuanhuang zhengjiao 先天佛道元皇正教) (T0009). Peng Zhongwei 彭鍾維, despite an ordination name (zouming), claims only the study of Buddhism which he has learned since his childhood from his master Zhou Mugui 周 木桂, born in 1892 and deceased in 1942 (Pl. 22). He received all his teachings and to thank his master he had a statuette made to whom he established a cult day and night. The soul of his master is always present in this wooden effigy, just as if he were alive, allowing the disciple and the master to never be separated, to be "the heart and the mouth in unison" (T0834). Luo 羅 and $\mathrm{Li}$ 李 have limited themselves to the orthodox religion of Lu Ban (T0575, T0513) and Wen Shengzhi 文盛志 to the “local artisans of color" (danqing chushi 丹 青處士) (T0043), that is to say the sculptors of statuettes, those who also prepare liturgical

${ }^{41}$ Elsewhere, the expression pengtui kaidao pogu 捧退開刀破骨 designate a kind of “bone-setter" who, with through talismans, secret formulas and lustral water, heals broken bones and open wounds. 
images, paper clothes for the divinities, etc.

The time of apprenticeship is marked by expressions, such as xiannian 先年 (in the preceding years), that do not allow the determination of a true duration, but others are more concrete. With the exception of two cases of masters taken since their tender youth and one initiation of five years, the majority indicate two years (qian nian 前年) or one year (shang nian 上年). Ouyang Fasheng 歐陽法笙 was born in 1880 and it is the eighth day of the second month of the year 1932, that Zhang Xiangui 張先桂, at the age of 29 sui, took him as a master of initiation. The apprenticeship was given briskly, since the sixteenth, seventeenth and eighteenth days of the tenth month of the same year the ordination ritual (paopai zouzhi 拋牌 奏職) took place. And it is on this occasion that the statue of the master was made and consecrated. One should suppose that the master died at the age of fifty-two (T0303).

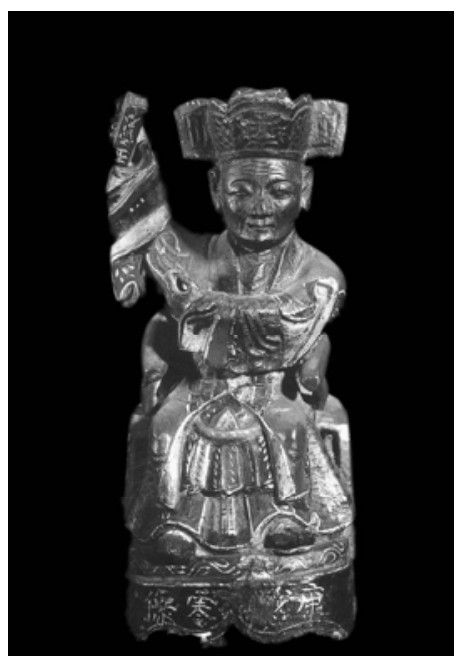

Pl. 21: Kang Miaoling ( 1783-?),

Xinhua, h. $22 \mathrm{~cm}, \mathrm{~T} 0166$

Cliche Claude DelhayeCEFEO

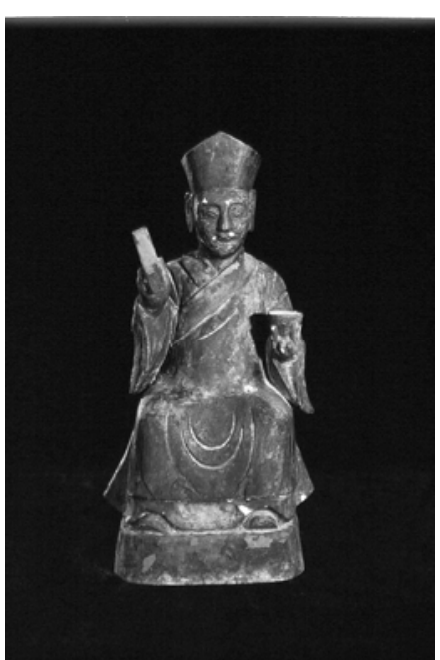

Pl. 22 : Zhou Mugui (1892-1942), Shaoyang, 1946, h. $21.6 \mathrm{~cm}$, T0834

Cliche Zhang Chaoyin $\subset$ EFEO

\section{Conclusions}

As they are today, it is easy to imagine that in the past several statuettes enthroned on family altars in Hunan (Pl. 23). Inevitably there would be one of the God of the Southern Peak, one of Guanyin, one of the God of the Kitchen, and one or two of the father, mother, grandfather, or grandmother. To this one should add, for initiates, a statuette of their master, maybe one of the founder of the order or of the master of the place. For guild members there would be one of Zhang Wulang for hunters, one of Lu Ban for builders, one of Yaowang for doctors, and one of the God of the Smithy for iron workers. One had to worship them 
regularly and summoned them in times of need; they also appeared during mediumistic séances intended to resolve the misfortunes afflicting a family. Thus we move from national divinities to universal local divinities, from local divinities rooted in a clan to very close relations, from spiritual masters to initiation masters. All had to be mixed and worshipped, in the moments and with the desired intensity. This phenomenon is not merely an epiphenomenon but concerns a vast region in southern China, a region in itself as big as half of France. Nonetheless the question remains: Why there and not elsewhere? What in particular exists in Hunan that does not exist elsewhere?

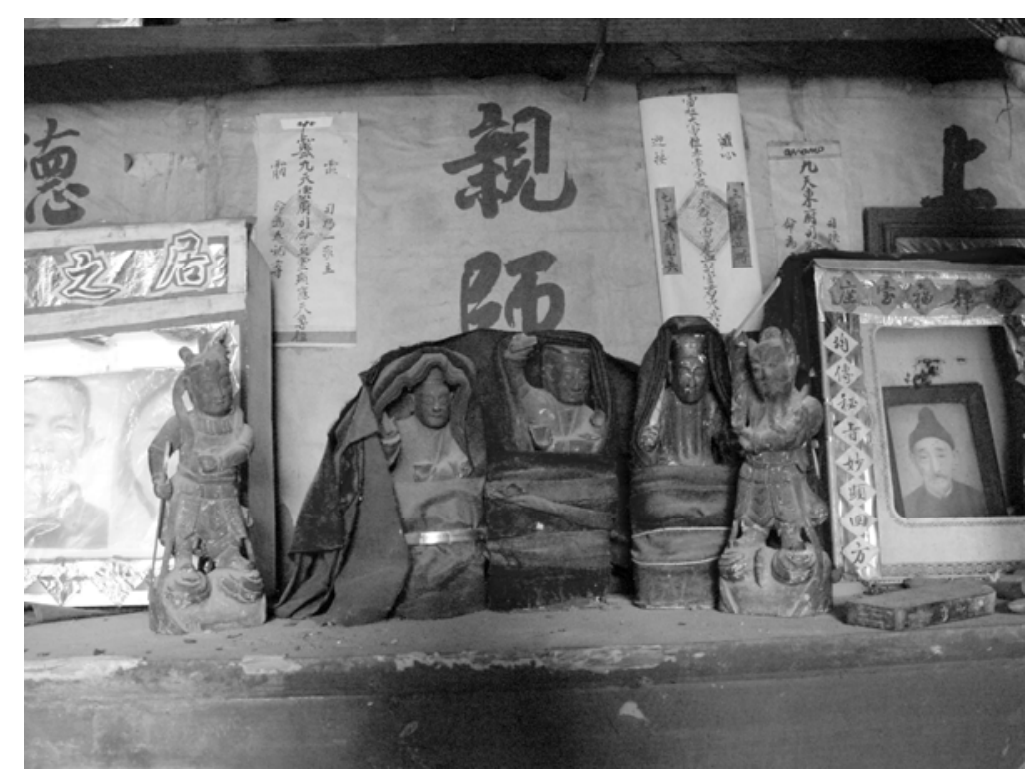

P1. 23: Detail of the Altar of a daoist priest; from left to right: photo of deceased son and daughter-in-law, statues of Marshal Yin, of Great grandfather's master, of Grandfather, of

Great grandfather, of Marshal Wang, photo of father; Anhua, Meicheng, 2003,

Cliche Alain Arrault

Classical authors and more modern ones repeat over and over that the people of Hunan, the partial heirs of Chu culture, are fond of divinities and move in a world filled with supernatural and demonic powers. We are thus in a logic of proliferation: if divinities, why not local divinities; if local divinities, why not masters; if masters, why not kin? After all, this omnipresence of the supernatural in the everyday is also the lot of all China, which has striven over the course of time to fatten its pantheons, and a cult-especially a polytheistic onemakes this proliferation a priori possible.

But this is not a real answer. It is of the sort that declares whether the chicken or the egg comes first; that the god or the cult has precedence. Are the gods there before, or do they only exist thanks to cults? A psychologist of religions would choose the first hypothesis; the need for the sacred is an integral part of human nature. A sociologist would opt for the second: gods 
only exist through cults and their social and communitarian associations. All this is true but tells us little.

Let us return to our specific case. The particularity of Hunan is the making of statues of relatives and masters. ${ }^{42}$ In other words, to place in the mass of spirits not only gods, universal and local, whose merits have in the course of history been patiently elaborated, but also individuals whose only merit is being deceased, as if death sufficed to immediately attain the superior status of spirit and enter into the celestial pantheon, without even the benefit of years and possibly miraculous events. The remarkable thing is that a great majority of statuettes are closely associated with liturgical instruments: the bowl of lustral water, the commanding staff, the buffalo's horn, or the making magical gestures with the hand, notably that of the sword. An equal majority of certificates log talismans intended to invoke divinities, a sort of personal register intended to provide the deceased a passport with which to enter into the spirit world and/or probably to protect the donors in their terrestrial life. Must one attribute this to the over-representation of exorcistic masters - individuals who have a true status conferred by the ordination ritual that this supposes - and not a simple sociological function varying according to circumstances? Could there have been in Central Hunan - where Daoism, like Buddhism, entered belatedly and with imperial troops (that is to say in the Song period) - the constitution of an order, that some call Yuanhuang, which initially submitted to the invaders by adapting their rituals, their instruments, their gods, their marshals, then preserved its cohort of local saints, of soldiers, and its local religious practices? In short, are we facing a religious phenomenon that was not entirely domesticated by the representatives of the State within the State? Are we facing popular religion, this phantom that has haunted Sinology for ages and which is sometimes rightly called into question because of the lack of specificity its definition? More precisely, are we facing the possibility, at once historic and ethnological, of touching the tips of the fingers of this phantom, which one calls by any name one wishes?

In attempting to answer these questions, we must continue with inquiries of three sorts: those concerning the documents already in our possession - the consecration certificateswhich still have so much to say regarding the concrete aspect of cults, and the great and minor divinities that are present in the part reserved for talismans; ethnological inquiries, about which some forty local researchers are already working, including local literati, officers in charge of culture and of religion, and religious specialists, sculptors; historical research drawing initially on "official" or less official writings in the local archives, including of course local monographs but above all familial genealogies, which sometimes prattle on about ancestors, their origin and their practices; and raw administrative data such as population registers, temple inventories, etc. If the picture is but a sketch, we must henceforth paint it in, for how true it is that "history is but imagination connected to the reality of archives" (Georges Duby).

\footnotetext{
${ }^{42}$ Yang Yanjie presents in the Hakka region situated in Fujian province a few cases of statuettes which are also made for the cult of great ancestors, but not for closed parents or masters. See Yang Yanjie, "Hua'nan minjian de zushen chongbai," 388-398, and "Minxi Kejia diqu de wuxian shen chongbai."
} 


\section{Bibliography}

ARRAULT, Alain. "Religious Practice in China: Preliminary Analyses of Religious Practices in Anhua District, Hunan Province, from the Qing Dynasty to the Present Day.” Paper presented at the ICAS-4, Shanghai, August 2005.

——. "Hunan shenxiang yanjiu chutan" 湖南神像研究初探. In Dao wenhua guoji xueshu yantao hui lunwen ji, 533-540. Gaoxiong: Guoli Gaoxiong Shifan daxue jingxue yanjiu suo, 2006.

—- ed., in collaboration with Michela Bussotti, Patrice FavA, Li Feng, ZhAng Yao et al. Les statuettes religieuses du Hunan. 1. La collection Patrice Fava (restricted access), http://www.shenxianghunan.com/bdd_web_barbara/index.html, EFEO, 2006.

_ , ed., in collaboration with Michela Bussotti, Deng Zhaohui, Li Feng, Shen Jinxian, ZHANG Yao. Les statuettes religieuses du Hunan. 2. La collection du musée du Hunan (restricted access), http://www.shenxianghunan.com/bdd_web_barbara/index.html, EFEO-Musée du Hunan, 2006.

“Qingdai yilai Hunan sheng shenxiang de chubu fenxi” 清代以來湖南省神像的初步 分析. Forthcoming.

__ and Michela BussotTI. "Statuettes religieuses et certificats de consécration en Chine du Sud (XVII $-\mathrm{XX}^{\mathrm{e}}$ siècle)." Arts Asiatiques 63 (2008): 36-59

BussotTI, Michela. "A Domestic Statuary." Paper presented at the ICAS-4, Shanghai, August 2005.

——. “Hunan zhongbu diqu 'Jiating diaoxiang' de lüeshu” 湖南中部地區家庭雕像的略述. Forthcoming.

—. "Rappresentazioni femminili nelle statuette religiose dell'Hunan centrale di epoca moderna e contemporanea." Paper presented at the Colloquium "La Cina e il mondo," Rome, Università la Sapienza, 2007.

— and Alain ARRAULT. "Statuaria popolare cinese: le sculture lignee dell'Hunan centrale e la collezione del Museo provinciale." DecArt 9 (2008): 2-13.

CHAN Winghoi. "Ordination Names in Hakka Genealogies: A Religious Practice and Its Decline. In Down to Earth, edited by David FaURE, Helen F. SIU, 65-82. Stanford: Stanford University Press, 1995.

CHEN Zi'ai and HUA Lan (Alain ARRAULT), ed. Xiangzhong zongjiao yu xiangtu shehui diaocha baogao ji 湘中宗教與鄉土社會調查報告集, 2 vols. Beijing: Zongjiao wenhua chubanshe, 2009, in press. Proceedings of the international colloquium "Xiangzhong zongjiao yu xiangtu shehui," Loudi, Shuiche, 24-29 June 2006.

DAVIS, Edward L. Society and the Supernatural in Song China. Honolulu: University of Hawai'i Press, 2001. 
Donnelly, Neal. Gods of Taiwan. A Collector's Account / Taiwan de shenxiang - yi ming Meiguo wenwu shoucang jia yanjiu jishi 台灣的神像 - 一名美國文物收藏家研究紀事. Taiwan, Yishu jia chubanshe, 2006.

EBrey, Patricia. "Portrait Sculptures in Imperial Ancestral Rites in Song China." T'oung Pao 83, 1-3 (1997): 42-91.

. "The Incorporation of Portraits into Chinese Ancestral Rites." In The Dynamics of Changing Rituals: the Transformation of Religious Rituals within their Social and Cultural Context, edited by Jens KREINATH et al., 129-140. New York: Peter Lang, 2004.

Emmons, Deirdre. Dieux de Chine. Le panthéon populaire du Fujian de J. J. M. de Groot. Lyon: Muséum d'histoire naturelle, Un, deux,...quatre Editions, 2003.

FANG Ling. Une tradition sacrée de la médecine chinoise ancienne. Etude sur le Livre des exorcismes de Sun Simiao (581-682). Paris: Collège de France, IHEC. Forthcoming.

FAVA, Patrice. La revanche de Han Xin. Un mystère taö̈ste/ Han Xin's Revenge. A Daoist Mystery. Paris, CNRS Images, 2005.

FENG Wangxing. “Lu Ban shu zai banwu jianzhu ji richang shenghuo zhong de yunyong” 魯 班術在板屋建築及日常生活中的運用. In CHEN Zi’ai and HUA Lan (Alain ARRAULT), ed., 908-921. Beijing: Zongjiao wenhua chubanshe, 2009, in press.

FENG Yunxing, “Fengjia shan jumin shenkan wenhua diaocha” 奉家山居民神音文化調查, in CHEN Zi'ai and HuA Lan (ARRAUlT Alain) ed., Xiangzhong zongjiao yu xiangtu shehui diaocha baogao ji, 687-699. Beijing: Zongjiao wenhua chubanshe, 2009. Forthcoming.

FU Juliang 傅聚良. “Hunan minjian mudiao shenxiang”湖南民間木雕神像. Zhongguo wenwu shijie 150 (1998): 54-68.

GuO Zhaoxiang 郭兆祥. Zhongguo meishan wenhua 中國梅山文化. Xianggang: Tianma dushu you xian chuban gongsi, 2002.

HuAnG, Susan. "Summoning the Gods: Paintings of the Three Officials of Heaven, Earth and Water and Their Association with Daoist Ritual Performance in the Southern Song Period (1127-1279)." Artibus Asiae 61.1 (2001): 5-52.

KATZ, Paul. Images of the Immortal: The Cult of Lü Dongbin at the Palace of Eternal Joy. Honolulu: University of Hawaii Press, 1999.

Li Huaisun 李懷槂. Hunan sheng Huitong xian Jinlong xiang Yanxi chong Meishan hujiang keyi ben 湖南省會同縣金龍鄉嚴溪沖梅山虎匠科儀本. In Zhongguo chuantong keyi ben huibian, vol. 5, edited by WANG Qiugui. Taipei: Xin wenfeng, 2001.

Li Xinwu 李新吾, “Lengshui jiang Yang Yuanzhang tan shigong yu daoshi de yitong bijiao” 冷水江楊源張壇師公與道士的異同比較, in CHEN Zi' ai and HUA Lan (Alain ARRAULT Alain) ed., Xiangzhong zongjiao yu xiangtu shehui diaocha baogao ji, 271-303. Beijing: 
Zongjiao wenhua chubanshe, 2009, in press.

LIN Wenrui 林文睿. Minsu qiwu tulu: Shenxiang pian 民俗器物圖錄 — 神像篇. Taipei: Guoli zhongyang tushu guan Taiwan fenguan, 1998.

LitTle, Stephen, and Shawn Eichman. Taoism and the Arts of China. Berkeley: University of California Press, 2000.

LIU Guozhong and TANG Haochu. "Lengshui jiang, Xinhua jinshu jiagong gongjiang xinyang xisu diaocha” 冷水江新化金屬加工工匠信仰習俗調查, in CHEN Zi'ai and HUA Lan (Alain ArRAUlT), ed., Xiangzhong zongjiao yu xiangtu shehui diaocha baogao ji, 778797. Beijing: Zongjiao wenhua chubanshe, 2009, in press.

LIU Wensan 劉文三. Taiwan shenxiang yishu 台灣神像藝術. Taipei: Yishu jia chuban she, 1995.

RobSOn, James, curated. "Inside Asian Images: An Exhibition of Religious Statuary from the Artasia Gallery Collection. Ann Arbor." Held at the Institute for the Humanities at the University of Michigan on January 22-26, 2007.

- Power of Place: The Religious Landscape of the Southern Sacred Peak (Nanyue) in Medieval China. Cambridge: Harvard University Asia Center, 2009.

STEVENS, Keith G. "Altar Images from Hunan and Kiangsi”. Journal of the Hong Kong Branch of the Royal Asiatic Society 18 (1978): 41-48. Illustrations 1-10 (end of the volume).

—_. "Portraits and Ancestral Images on Chinese Altars." Arts of Asia19.1 (1989):135-145.

- Chinese Gods: The Unseen World of Spirits and Demons. London: Collins and Brown, 1997.

Unschuld, Paul U. Medicine in China. Historical Artifacts and Images. Munich, London, New York, Prestel, 2000.

Werblowski, Zwi, "Catalogue of the Pantheon of Fujian Popular Religion." Studies in Central and East Asian Religions, 12/13 (2001): 95-186.

WU Qiming. “Qingxu dao si xianzhen diaocha baogao” 清虛島四仙真調查報告. In CHEN Zi'ai and HUA Lan (Alain ARRAULT), ed., Xiangzhong zongjiao yu xiangtu shehui diaocha baogao ji, 108-138. Beijing: Zongjiao wenhua chubanshe, 2009, in press.

XIA Feng 夏風. Minjian mudiao yu tu'an: Zaoxiang juan 民間木雕與圖案一造像卷. Hangzhou: Zhejiang daxue chubanshe, 2004.

YANG Yanjie 楊彥傑. “Hua’nan minjian de zushen chongbai” 華南民間的祖神崇拜. Faguo hanxue / Sinologie française 5 (2000): 388-398.

. “Minxi Kejia diqu de zuxian shen chongbai”闽西客家地区的祖先神崇拜. http://140.115.170.1/speech/9210/921029-01.pdf, accessed on January 2009. 
YE Mingsheng 葉明生 and WANG Chiu-kuei 王秋桂 (ed.). Fujian Longyan shi Dongxiao zhen Lüshan jiao Guangji tan keyi ben huibian 福建龍嚴市東肖鎮閭山教廣濟壇科儀本 彙編. Taipei: Taiwan Xinwenfeng chuban gongsi, 1996.

—. Fujian Shouning xian Lüshan Liyuan kejiao yiben huibian 福建壽寧縣閭山梨園科教 儀本彙編. Taipei: Taiwan Xinwenfeng chuban gongsi, 2007.

——, and John LAGERWEY. Fujian sheng Jianyang shi Lüshan jiao keyi ben huibian 福建省 建陽市閭山教科儀式本彙編. Taipei: Taiwan Xinwenfeng chuban gongsi, 2007. 